\title{
Contribution of dental private practitioners to publications on anatomical variations using cone beam computed tomography.
}

\section{Authors: \\ Hebda $A^{1, *} M S$, Theys $S^{2}$ DDS, \\ De Roissart $J^{3} \mathrm{MD}$, \\ Perez $\mathrm{E}^{4} \mathrm{DDS}$, \\ Olszewski $\mathrm{R}^{1,3} \mathrm{DDS}, \mathrm{MD}, \mathrm{PhD}, \mathrm{DrSc}$}

\footnotetext{
Affiliations:

${ }^{1}$ Oral and maxillofacial surgery research Lab, NMSK, IREC, SSS, UCLouvain, Brussels, Belgium

${ }^{2}$ Department of pediatric dentistry and special care, Cliniques universitaires saint Luc, UCLouvain, Brussels, Belgium

${ }^{3}$ Department of oral and maxillofacial surgery, Cliniques universitaires saint Luc, UCLouvain, Brussels, Belgium

${ }^{4}$ Department of orthodontics, Cliniques universitaires saint Luc, UCLouvain, Brussels, Belgium

*Corresponding author: Hebda A, Oral and maxillofacial surgery research Lab, NMSK, IREC, SSS, UCLouvain, Brussels, Belgium, ORCID Id 0000-0001-51110021
} 
44

45

46

47

48

49

50

51

52

53

54

55

56

57

58

59

60
Disclaimer: the views expressed in the submitted article are our own and not an official position of the institution or funder. 


\begin{abstract}
Objective: To investigate the participation of citizens-dental private practitioner in scientific articles about anatomical variations on dentomaxillofacial CBCT. Our null hypothesis was that private practice practitioners are not involved in publications on anatomical variations using cone beam computed tomography.
\end{abstract}

Material and methods: This study was performed from home without access to our university library. Only PubMed database was used to perform our study. We found 384 articles published among 1830 articles corresponding to our inclusion/exclusion criteria. For each selected article we searched for affiliation of all of the authors (university, private dental practice, students, other). We applied a co-creation approach to involve colleagues from private practice in analyzing results of this study.

Results: A large majority of authors have university affiliation (96.5\%). Only 3\% of authors come from private practice. Most of articles belong to the group of 7 emergent economies (E7), and from Asia. 47.9\% of 96 journals published only one article on anatomical variations discovered on CBCT. The higher number of articles $(18.75 \%)$ were published by journals related to endodontics. The $84 \%$ of articles were dispersed among a vast span of general and specific dental, and maxillofacial journals. The $68.4 \%$ of articles on variations in CBCT were available in closed access and $31.6 \%$ of articles were available in open access. Only $6.7 \%$ of articles were published in open access without author publication charges (APC). The $31.6 \%$ of authors with university affiliation choose open access for their article. $7.8 \%$ of authors from private practice were involved in publishing in closed access journals and $2.34 \%$ in open access journals. Only 3 articles $(0.78 \%)$ were published by authors affiliated to private practice without involvement of university authors. $2.6 \%$ of articles involved students as co-authors. Authors with other affiliation were involved only in one closed access publication. For the step of co-creation none of 183 private practitioners, and 3/33 (9\%) university-affiliated members of Nemesis Facebook group actively participated in analyzing the results of this study.

Conclusions: the null hypothesis was accepted: dentists from private practice are exceptionally involved in publications on anatomical variations using CBCT in dentomaxillofacial area.

Keywords: cone beam computed tomography, CBCT, anatomical variation, citizen science, open access 


\section{Introduction}

Citizen participative science is emerging part of open science practices. Open science means sharing as early as possible and not only between academics but with non-academics as well (https://discovery.ucl.ac.uk/id/eprint/10058422/ ). In medical research, participative science is not very popular. Patients are only considered as subject of the research, and sharing knowledge and data with patients is difficult because of the medical secret and of data protection. However, word "citizen" in citizen participative science refers to voluntary participation by nonprofessional contributors or professional contributors not involved in academic career. Building on our previous article on accessibility to the knowledge on anatomical variations from dentomaxillofacial cone beam computed tomography (CBCT) we found that articles on that topic with free open access represent an exception in dental literature [1]. Private practitioners were not able to quickly find pertinent reference figures on anatomical variation arising in dentomaxillofacial $\mathrm{CBCT}$ imaging [1]. The objective of our article was double: 1) to investigate the participation of citizens-dental private practitioner in scientific articles on anatomical variations on dentomaxillofacial $\mathrm{CBCT}$, and 2) to involve citizens-private practice practitioners as well as their scholarly colleagues in analyzing results on the present study, and to evaluate the issues and limitations of this approach. Our null hypothesis was that private practice practitioners are not involved in publications on anatomical variations using cone beam computed tomography.

\section{Materials and methods}

The study was performed from home without access to our university library. We worked in the same experimental conditions as our private practice colleagues to access free scientific knowledge. We used some elements from systematic review methodology to find articles in a reproducible manner. The Scopus (institutional access only) and Embase (payment) databases were not used. Only PubMed database was used to perform our study. We wanted to search as many as possible articles on anatomic variations discovered and/or described in studies using CBCT. Our research equation for PubMed was set as follow:

(CBCT[All Fields] AND ("anatomy and histology"[Subheading] OR ("anatomy"[All Fields] AND "histology"[All Fields]) OR "anatomy and histology"[All Fields] OR "anatomy"[All Fields] OR "anatomy"[MeSH Terms])) AND (hasabstract[text] AND "humans"[MeSH Terms] AND (English[lang] OR French[lang])). We accessed on PubMed on 24.07.2019.

There was no time frame for our search (1948-2019). The languages selected were English and French. The inclusion criteria were set as follow: studies on CBCT on human anatomical variation in dentomaxillofacial area, studies with abstract.

Clinical studies, case series and case reports were also selected. 
The exclusion criteria were: experimental studies, in vitro studies, cadaver studies, studies without information on anatomical variation in dentomaxillofacial CBCT area, CBCT studies other than on dentomaxillofacial area, no author information, no abstract.

One observer performed the search. The research equation provided with 1830 articles. Articles were then selected according to inclusion/exclusion criteria on lecture of title and abstract. Articles were also excluded because of insufficient information on author affiliation in PubMed database or on the journal webpage. Finally, we found 384 articles [2-385].

For each selected article, we searched for affiliation of all of the authors. We needed to search the information about author affiliation on the journal webpage when it was not directly accessible from PubMed database. We subdivided affiliations onto: 1) University, 2) private practice, 3) student, 4) other occupation. Mixed affiliation university and private practice was considered as university affiliation as the author was able to use university access to his/her study. The student affiliation was reserved for student before final graduation (not $\mathrm{PhD}$ students). We used the category "other occupation" for radiological technicians.

We searched information about author's countries, and on journals publishing on anatomical variations using CBCT. We wanted to know about the involvement of different categories of authors in open access publication. We systematically accessed to all journals webpages of all selected articles. We checked if the pdf file was really accessible in open access journals. We searched for information on open access type in instruction for authors which were of two types: with and without author publication charges (APC).

The next step of methodology consisted of a co-creation approach to involve colleagues from our and other university dental departments, and from private practice in analyzing results and in writing conclusions.

A first draft of the article, composed of methodology and of 4 tables (Tables 1, 2, 13 , and 14) with search results was published on the website of Nemesis. This was formulated as an invitation to participate in the article and to write the analysis of results. The Nemesis journal uses also social media - a group was created on Facebook (in April 2020), where 228 members have subscribed. There were 183 private practitioners and 33 university affiliated members. The invitation and the link to the draft was posted on Facebook (19 May 2020). One month deadline (until 19 June 2020) was set in to contribute to the article drafting. Potential participants have been informed that this is an experimental approach and were given the possibility to contact the editor-in-chief for any question.

After one month, all contributions have been collected by email and incorporated to the new draft. All participants were given a new opportunity to comment through a new invitation and link to the $2^{\text {nd }}$ draft posted on Facebook. This time the participants were also asked to give their feedback why they think that so little private practice dentist are participating in scientific research and publication. 


\section{Results}

From the Table 1 we can see that publication on CBCT anatomical variations started from 1999 onwards. Total number of articles on CBCT anatomical variations was multiplied by 7 comparing the same period of time before and after 2011. Total number of authors was multiplied by 20 comparing the same period of time before and after 2011. The number of authors/article tripled after 2011. A vast majority of authors have university affiliation $(96.5 \%)$. Only 3\% of authors come from private practice. Student involvement in publications is almost inexistent $(0.5 \%)$. Between 2011-2019 appears a small but progressive lack of correct information on authors on Pubmed, and in the same period of time correct information on authors is achieved in scholarly journals.

Table 1. Information on included and excluded articles and on number and type of author's affiliation.

\begin{tabular}{|c|c|c|c|c|c|c|c|c|c|}
\hline Years & $\begin{array}{c}\text { Number } \\
\text { of } \\
\text { articles }\end{array}$ & $\begin{array}{c}\text { Number } \\
\text { of } \\
\text { authors }\end{array}$ & $\begin{array}{c}\text { Number } \\
\text { of } \\
\text { included } \\
\text { articles }\end{array}$ & $\begin{array}{l}\text { Number } \\
\text { of ex- } \\
\text { cluded } \\
\text { articles }\end{array}$ & $\begin{array}{l}\text { Number of } \\
\text { excluded } \\
\text { articles } \\
\text { with } \\
\text { insufficient } \\
\text { information }\end{array}$ & $\begin{array}{c}\text { Number } \\
\text { of } \\
\text { authors } \\
\text { with } \\
\text { univer- } \\
\text { sity af- } \\
\text { filiation }\end{array}$ & $\begin{array}{c}\text { Number } \\
\text { of } \\
\text { private } \\
\text { practice } \\
\text { authors }\end{array}$ & $\begin{array}{c}\text { Number } \\
\text { of } \\
\text { student } \\
\text { authors }\end{array}$ & $\begin{array}{c}\text { Number of } \\
\text { other } \\
\text { type of } \\
\text { affiliations } \\
\text { authors }\end{array}$ \\
\hline $\begin{array}{l}2015- \\
2019\end{array}$ & 800 & 1049 & 214 & 567 & 19 & 1002 & 40 & 7 & 0 \\
\hline $\begin{array}{l}2011- \\
2015\end{array}$ & 800 & 737 & 152 & 620 & 28 & 720 & 13 & 4 & 0 \\
\hline $\begin{array}{l}1999- \\
2011\end{array}$ & 230 & 84 & 18 & 210 & 2 & 80 & 3 & 0 & 1 \\
\hline $\begin{array}{l}1999- \\
2019\end{array}$ & $\begin{array}{l}\text { TOTAL } \\
=1830\end{array}$ & 1870 & 384 & 1397 & 49 & 1802 & 56 & 12 & 1 \\
\hline
\end{tabular}

The total number of articles from Tables 2-12 $(n=475)$ is different from 402 articles from Tables 1, 13, and 14. Some articles were written together by colleagues from different countries, and counted separately for each country. United States and Turkey are the most publishing country on CBCT anatomical variations (Table 2). Most of articles come from the group of 7 emergent economies (E7) (Table 4), and from Asia (Table 10). Publications on CBCT variations in European Union (Table 5) with the longest scholarly traditions are below G7 (Table 3) and BRICS (Table 6) countries. The 8 of 10 European countries from ex-sovietic bloc have no published articles on CBCT variations in PubMed. Russia also has no oarticle on that topic. When we compare the continents, $44.7 \%$ of articles belong to Asia (Table 10), $25.3 \%$ to Europe (Tables 5, 7), 15.4\% to North America (Table 8), and 12.1\% to South America (Table 9). Africa (Table 11), and Oceania (Table 12) are deeply underrepresented (Fig. 1). 
Table 2. The total number of articles by authors countries. The list of countries is arranged alphabetically for the same number of articles.

\begin{tabular}{|l|l|}
\hline Country of affiliated authors & $\begin{array}{l}\text { The total number } \\
\text { of articles }\end{array}$ \\
\hline USA & 67 \\
\hline Turkey & 67 \\
\hline Brazil & 49 \\
\hline China & 38 \\
\hline India & 31 \\
\hline South Korea & 19 \\
\hline Spain & 19 \\
\hline UK & 17 \\
\hline Japan & 16 \\
\hline Switzerland & 16 \\
\hline Italy & 15 \\
\hline Germany & 11 \\
\hline Romania & 11 \\
\hline Iran & 8 \\
\hline Taiwan & 8 \\
\hline Belgium & 6 \\
\hline Portugal & 6 \\
\hline Canada & 5 \\
\hline France & 5 \\
\hline Hong-Kong & 5 \\
\hline Israel & 5 \\
\hline Saudi Arabia & 5 \\
\hline Australia & 4 \\
\hline Egypt & 4 \\
\hline Malaysia & 4 \\
\hline Croatia & 3 \\
\hline Greece & 3 \\
\hline Poland & 3 \\
\hline South Africa & 3 \\
\hline Argentina & 2 \\
\hline Chili & 1 \\
\hline Syria & 1 \\
\hline The Netherlands & 1 \\
\hline Belarus & 1 \\
\hline Costa Rica & 2 \\
\hline Danmark & 1 \\
\hline Finland & 1 \\
\hline Georgia & 1 \\
\hline Iceland & 1 \\
\hline Iraq & 1 \\
\hline Jamaica & 1 \\
\hline Mexico & $19 n$ \\
\hline
\end{tabular}




\begin{tabular}{|l|l|}
\hline Norway & 1 \\
\hline Oman & 1 \\
\hline Thailand & 1 \\
\hline Venezuela & 1 \\
\hline Total=47 countries & Total $=475$ articles \\
\hline
\end{tabular}

Table 3. The total number of articles by countries belonging to G7 (major developed countries).

\begin{tabular}{|l|l|}
\hline Country & The total number of articles \\
\hline USA & 67 \\
\hline UK & 17 \\
\hline Japan & 16 \\
\hline Italy & 15 \\
\hline Germany & 11 \\
\hline France & 5 \\
\hline Canada & 5 \\
\hline Total= 7 & Total $=136$ \\
\hline
\end{tabular}

Table 4. The total number of articles by countries belonging to E7 (emerging economy countries).

\begin{tabular}{|l|l|}
\hline Country & The total number of articles \\
\hline Turkey & 67 \\
\hline Brazil & 49 \\
\hline China & 38 \\
\hline India & 31 \\
\hline Mexico & 1 \\
\hline Indonesia & 0 \\
\hline Russia & 0 \\
\hline Total=7 & Total $=186$ \\
\hline
\end{tabular}

Table 5. The total number of articles by countries belonging to European Union.

\begin{tabular}{|l|l|}
\hline Country & The total number of articles \\
\hline Spain & 19 \\
\hline Italy & 15 \\
\hline Germany & 11 \\
\hline Romania & 11 \\
\hline Belgium & 6 \\
\hline Portugal & 6 \\
\hline France & 5 \\
\hline Croatia & 3 \\
\hline Greece & 3 \\
\hline Poland & 3 \\
\hline The Netherlands & 2 \\
\hline Denmark & 1 \\
\hline Finland & 1 \\
\hline Austria & 0 \\
\hline
\end{tabular}




\begin{tabular}{|l|l|}
\hline Bulgaria & 0 \\
\hline Cyprus & 0 \\
\hline Estonia & 0 \\
\hline Hungary & 0 \\
\hline Ireland & 0 \\
\hline Latvia & 0 \\
\hline Lithuania & 0 \\
\hline Luxembourg & 0 \\
\hline Malta & 0 \\
\hline Czechia & 0 \\
\hline Slovakia & 0 \\
\hline Slovenia & 0 \\
\hline Sweden & 0 \\
\hline Total= 27 & Total=86 \\
\hline
\end{tabular}

Table 6. The total number of articles by countries belonging to BRICS countries.

\begin{tabular}{|l|l|}
\hline Country & The total number of articles \\
\hline Brazil & 49 \\
\hline China & 38 \\
\hline India & 31 \\
\hline South Africa & 3 \\
\hline Russia & 0 \\
\hline Total=5 & Total $=121$ \\
\hline
\end{tabular}

Table 7. The total number of articles by countries belonging to European countries other than European Union.

\begin{tabular}{|l|l|}
\hline Country & The total number of articles \\
\hline UK & 17 \\
\hline Switzerland & 16 \\
\hline Belarus & 1 \\
\hline Iceland & 1 \\
\hline Norway & 1 \\
\hline Total=5 & Total $=36$ \\
\hline
\end{tabular}

Table 8. The total number of articles by countries in North America.

\begin{tabular}{|l|l|}
\hline Country & The total number of articles \\
\hline USA & 67 \\
\hline Canada & 5 \\
\hline Mexico & 1 \\
\hline Total=3 & Total=73 \\
\hline
\end{tabular}

Table 9. The total number of articles by countries in South America.

\begin{tabular}{|l|l|}
\hline Country & The total number of articles \\
\hline Brazil & 49 \\
\hline Argentina & 2 \\
\hline
\end{tabular}




\begin{tabular}{|l|l|}
\hline Chili & 2 \\
\hline Costa Rica & 1 \\
\hline Jamaica & 1 \\
\hline Venezuela & 1 \\
\hline Total=6 & Total $=56$ \\
\hline
\end{tabular}

Table 10. The total number of articles by countries in Asia.

\begin{tabular}{|l|l|}
\hline Country & The total number of articles \\
\hline Turkey & 67 \\
\hline China & 38 \\
\hline India & 31 \\
\hline South Korea & 19 \\
\hline Japan & 16 \\
\hline Iran & 8 \\
\hline Taiwan & 8 \\
\hline Hong-Kong & 5 \\
\hline Israel & 5 \\
\hline Saudi Arabia & 5 \\
\hline Malaysia & 4 \\
\hline Syria & 2 \\
\hline Georgia & 1 \\
\hline Iraq & 1 \\
\hline Jordan & 1 \\
\hline Thailand & 1 \\
\hline Oman & 1 \\
\hline Total=17 & Total=213 \\
\hline
\end{tabular}

Table 11. The total number of articles by countries in Africa.

\begin{tabular}{|l|l|}
\hline Country & The total number of articles \\
\hline Egypt & 4 \\
\hline South Africa & 3 \\
\hline Total= 2 & Total=7 \\
\hline
\end{tabular}

Table 12. The total number of articles by countries in Oceania. 
Fig. 1. The total number of articles by continents.

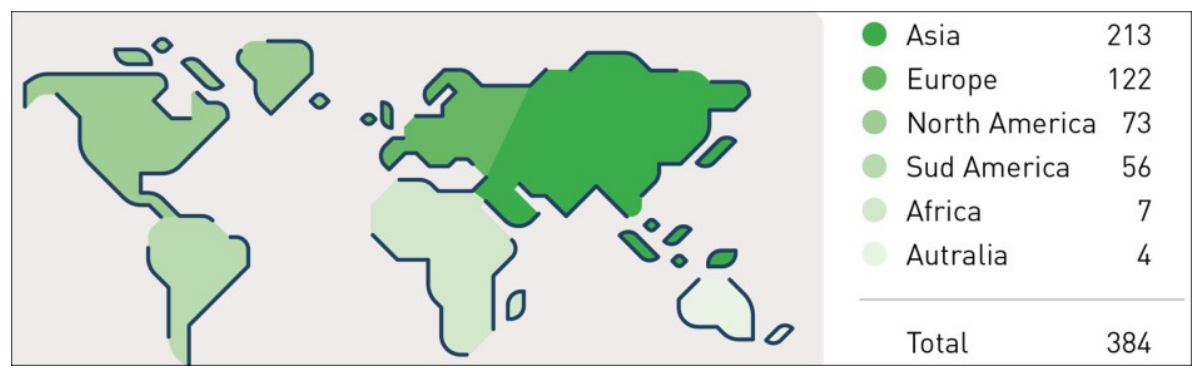

The 46 of 96 journals (47.9\%) published only one article on anatomical variations discovered on CBCT (Table 13). The higher number of articles (18.75\%) were published by journals related to endodontics. Journal with the scope of dentomaxillofacial radiology accepted only $15.36 \%$ of all articles on anatomical variations on $\mathrm{CBCT}$. Therefore, $84 \%$ of articles were dispersed among a large span of general and specific dental, and maxillofacial journals.

Table 13. The total number of articles by journal titles. The list of journals is arranged alphabetically for the same number of articles.

\begin{tabular}{|l|l|}
\hline Journal Title & The total number of articles \\
\hline J Endod & 54 \\
\hline Surg Radiol Anat & 42 \\
\hline Int Endod J & 17 \\
\hline J Craniofac Surg & 13 \\
\hline $\begin{array}{l}\text { Oral Surg Oral Med Oral Pathol } \\
\text { Oral Radiol }\end{array}$ & 13 \\
\hline Clin Oral Investig & 11 \\
\hline Clin Implant Dent Relat Res & 10 \\
\hline Dentomaxillofac Radiol & 10 \\
\hline Implant Dent & 9 \\
\hline J Contemp Dent Pract & 8 \\
\hline Int J Oral Maxillofac Surg & 7 \\
\hline Rom J Morphol Embryol & 7 \\
\hline Acta Odontol Scand & 6 \\
\hline Am J Orthod Dentofacial Orthop & 6 \\
\hline Braz Dent J & 6 \\
\hline Braz Oral Res & 6 \\
\hline Head Face Med & 5 \\
\hline Indian J Dent Res & 5 \\
\hline J Oral Maxillofac Surg & 5 \\
\hline Niger J Clin Pract & 5 \\
\hline PLoS One & 5 \\
\hline Ann Anat & 4 \\
\hline Arch Oral Biol & 4 \\
\hline & \\
\hline
\end{tabular}




\begin{tabular}{|c|c|}
\hline Clin Oral Implant Res & 4 \\
\hline Eur J Orthod & 4 \\
\hline Forensic Sci Int & 4 \\
\hline J Forensic Sci & 4 \\
\hline J Formos Med Assoc & 4 \\
\hline Med Oral Patol Oral Cir Bucal & 4 \\
\hline Minerva Stomatol & 4 \\
\hline Oral Maxillofac Surg & 4 \\
\hline Angle Orthod & 3 \\
\hline Biomed Res Int & 3 \\
\hline BMC Med Imaging & 3 \\
\hline $\mathrm{Br} \mathrm{J}$ Oral Maxillofac Surg & 3 \\
\hline Dent Clin North Am & 3 \\
\hline Eur Arch Otorhinolaryngol & 3 \\
\hline Int J Oral Sci & 3 \\
\hline J Appl Oral Sci & 3 \\
\hline $\mathrm{J}$ Craniomaxillofac Surg & 3 \\
\hline J Oral Implantol & 3 \\
\hline Acta Odontol Latinoam & 2 \\
\hline Aust Dent J & 2 \\
\hline BMC Oral Health & 2 \\
\hline Clin Anat & 2 \\
\hline J Forensic Leg Med & 2 \\
\hline $\mathrm{J}$ Investig Clin Dent & 2 \\
\hline J Oral Rehabil & 2 \\
\hline Med Princ Pract & 2 \\
\hline Sci Rep & 2 \\
\hline Acta Med Acad & 1 \\
\hline Acta Radiol & 1 \\
\hline Anat Sci Int & 1 \\
\hline Aust Endod J & 1 \\
\hline Br Dent J & 1 \\
\hline Bull Tokyo Dent Coll & 1 \\
\hline Clin Imaging & 1 \\
\hline Compend Contin Educ Dent & 1 \\
\hline Cranio & 1 \\
\hline Dental Press J Orthod & 1 \\
\hline Dent Traumatol & 1 \\
\hline Diagn Interv Radiol & 1 \\
\hline Eur Rev Med Pharmacol Sci & 1 \\
\hline Folia Morphol (Warsz) & 1 \\
\hline Georgian Med News & 1 \\
\hline Ger Med Sci & 1 \\
\hline In Vivo & 1 \\
\hline Int Dent J & 1 \\
\hline Int J Artif Organs & 1 \\
\hline Int J Legal Med & 1 \\
\hline Int J Pediatr Otorhinolaryngol & 1 \\
\hline
\end{tabular}




\begin{tabular}{|l|l|}
\hline J Am Dent Assoc & 1 \\
\hline J Anat & 1 \\
\hline J Clin Periodontol & 1 \\
\hline J Coll Physicians Surg Pak & 1 \\
\hline J Dent Child (Chic) & 1 \\
\hline J Indian Soc Pedod Prev Dent & 1 \\
\hline J Oral Sci & 1 \\
\hline J Orthod & 1 \\
\hline J Prosthet Dent & 1 \\
\hline J Prosthodont & 1 \\
\hline J Zhejiang Univ Sci B & 1 \\
\hline Leg Med (Tokyo) & 1 \\
\hline Med Sci Monit & 1 \\
\hline Microsc Res Tech & 1 \\
\hline Morphologie & 1 \\
\hline Mymensingh Med J & 1 \\
\hline Odontology & 1 \\
\hline Okajimas Folia Anat Jpn & 1 \\
\hline Oral Dis & 1 \\
\hline Orthod Craniofac Res & 1 \\
\hline Prog Orthod & 1 \\
\hline Radiol Med & 1 \\
\hline Rev Stomatol Chir Maxillofac & 1 \\
\hline Saudi Med J & 1 \\
\hline Sultan Qaboos Univ Med J & 1 \\
\hline Total= 96 journals & Total=384 articles \\
\hline & \\
\hline
\end{tabular}

The $68.4 \%$ of articles on variations in $\mathrm{CBCT}$ were available in closed access, and $31.6 \%$ of articles were available in open access (Table 14 ). However, only $6.7 \%$ of articles were published in open access without author publication charges (APC). The $31.6 \%$ of authors with university affiliation choose open access for their article. The $24.7 \%$ of authors with university affiliation published in journals with open access and APC. The $6.7 \%$ of authors with university affiliation published in journals with open access and without APC. The 7.8\% of authors from private practice were involved in publishing in closed access journals and $2.34 \%$ in open access journals. Only 3 articles $(0.78 \%)$ were published by authors affiliated to private practice without involvement of university authors. Students were involved as co-authors in $2.6 \%$ of articles. Authors with other affiliation were involved only in one closed access publication (Fig. 2.). 
Table 14. Open and closed access publication type for selected articles.

\begin{tabular}{|l|l|l|l|l|l|l|l|l|l|l|}
\hline & $\begin{array}{l}\text { CA } \\
+ \\
\text { UNI }\end{array}$ & $\begin{array}{l}\text { CA + } \\
\text { UNI } \\
+ \\
\text { Priv }\end{array}$ & $\begin{array}{l}\text { CA + } \\
\text { UNI } \\
+\end{array}$ & $\begin{array}{l}\text { Student } \\
\text { Priv }\end{array}$ & $\begin{array}{l}\text { CA + } \\
\text { UNI + } \\
\text { Tech }\end{array}$ & $\begin{array}{l}\text { OA + } \\
\text { APC+ } \\
\text { UNI }\end{array}$ & $\begin{array}{l}\text { OA + } \\
\text { APC } \\
+ \text { UNI } \\
+ \\
\text { Priv }\end{array}$ & $\begin{array}{l}\text { OA + } \\
\text { APC + } \\
\text { UNI + } \\
\text { Student }\end{array}$ & $\begin{array}{l}\text { OA } \\
\text { with } \\
\text { NO } \\
\text { APC + } \\
\text { UNI }\end{array}$ & $\begin{array}{l}\text { OA } \\
\text { with } \\
\text { NO } \\
\text { APC + } \\
\text { UNI + } \\
\text { Priv }\end{array}$ \\
\hline $\begin{array}{l}\text { Total= } \\
384 \\
\text { articles }\end{array}$ & 226 & 27 & 6 & 3 & 1 & 84 & 7 & 4 & 24 & 2 \\
\hline
\end{tabular}

CA: closed access, OP: open access, APC: author publication charges, UNI: author university affiliation, Priv: author private practice affiliation, Student: author is a student from a given university, Tech: author is a technician affiliated to Unversity clinic.

Fig. 2. The total number of articles related to the type of access, and presence or absence of author publication charges.
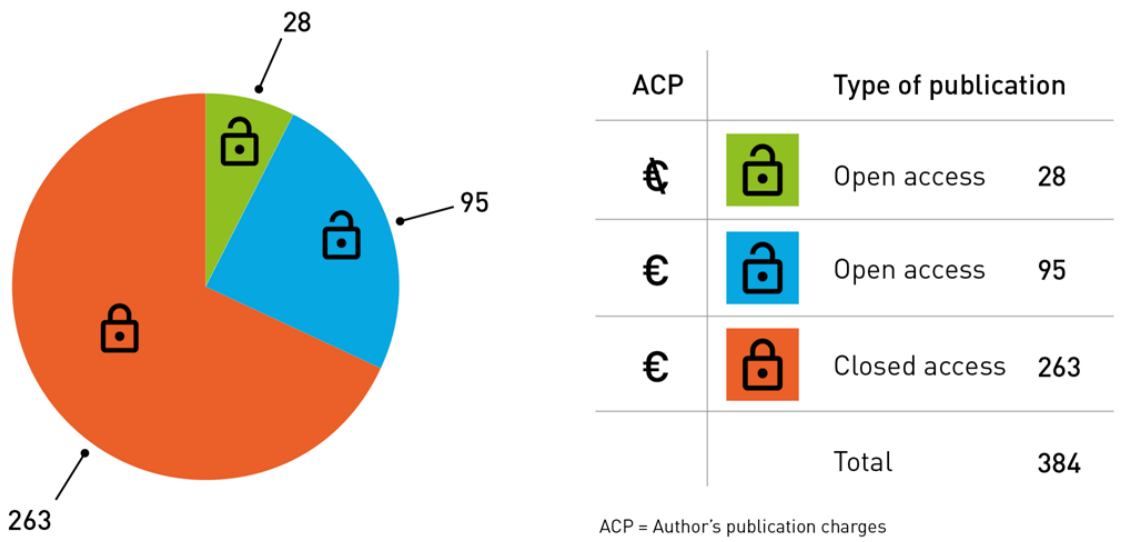

For the step of co-creation only 3 of $33(9 \%)$ university affiliated members of Nemesis Facebook group answered after the first call, and one university affiliated member answered again after the second call. There was no involvement of any of 183 private practitioners from Nemesis Facebook group.

\section{Discussion}

The interest in describing human anatomical variation discovered on CBCT is increasing in scholarly literature (Table 1). However, the role of private practitioner in its development is not significant (Table 1). Various hypotheses can be put forward to explain the low participation of private practitioners without university affiliation in scientific publications on anatomical variations on CBCT. The research 
itself and the science community may be difficult to access and seems to be reserved to a kind of elite. Scientific literature is not easily accessible as the majority of articles are accessible under closed access-paywalls (Table 14, Fig. 2). There exists a real difficulty for private practitioner to produce a publication with sufficient quality required by scholarly journals, and without any collaboration with scholarly experts (methodology aspects, scientific writing, publication process). The private practitioner may also feel overwhelmed by the large number of scientific publications and thus not feel up to date or not feel able to make an original contribution. The private practitioner may lack training in analyzing the whole CBCT field of view, and remain focused only on their area of interest. They may therefore not observe the anatomical variations. There may be a lack of details in received protocols as they only answer to question asked by practitioners. The latter is not aware of the existence of anatomical variations. Another difficulty may come from access to the CBCT device which is more difficult in private practice than in hospitals and/or university clinics even if this tends to improve in recent years.

Quantity of articles related to anatomical variations on CBCT is in relation with the economic power of given country, geographic area, or economic club (Tables 2-12). Articles are written in areas where there is an easy access to CBCT technology. CBCT is still expansive in comparison with conventional dental radiography. It needs the national implementation of special laws for patients radioprotection, and its safe and justified use by the dental practitioner. There is also a major need of post-university education for dentists, and maxillofacial surgeons using CBCT on daily basis, as CBCT was only introduced in dental practice from 2003. CBCT is also used for advanced dentistry (endodontics, implantology) which can be performed only in economically stable countries due to higher costs.

Prevalence and type of anatomical variations seen on CBCT are different for different human populations $[3,13-15,22,23,26,35,38,64,69,79,84,88,94,99$, $103,106,128,131,150,151,153,162,170,174,177,178,181,197,202,209,212$, $217,226,229,230,232,241,244,245,253,255,270,279,282,288,293,297,303$, $308,313,323,325,327,343,346,349,358,360,364,370,378]$. Some populations are currently better described than other $(55.4 \%$ of articles from Asia vs $31.7 \%$ from Europe). Anatomical variations on dentomaxillofacial CBCT still wait to be discovered on continents such as Africa and Oceania.

There is no real recognized leader journal which may accept the majority of articles related to anatomic variations discovered on CBCT (Table 13). Such articles may be single case reports that are known to be further less cited. Therefore, they will not be or be scarcely accepted by Editors as they do not contribute to increase the impact factor of a given journal.

In present situation a great majority of scholarly authors have no chance to access to all of these journals through their university library, as they library should subscribe to all of the titles from Table 13. Private practitioners have no chance at all to quickly access to the information they need immediately when they are confronted with a specific CBCT case in their own practice. 
Variation of root canals in CBCT seems to be an overrepresented topic. From the other hand, one article on a selected topic cannot itself embrace all the complexity of a given type of CBCT variation.

Open access is an option more and more selected by university affiliation authors (Table 14, Fig. 2). It seems not known by authors from private practice. However, closed access to articles on CBCT anatomical variations is still the most prevalent. This situation limits the advancement of research on human CBCT variations in dentomaxillofacial area by scholarly authors with limited budget. Moreover, dentists from private practice have no guarantee to find any reference figure to immediately compare with their clinical case in the paid (closed access) article. Dental journals without APC are very rare [1], and therefore articles with open access without APC are still the rarest type of publication.

In our study, we decided to involve citizens, which are private practice dentists not involved in any academic career. The incentive for active participation in our research was to become co-author of the final version of the article. We also granted the personalized contact with the Editor-in-Chief to overcome shyness of private practitioners. However, none of 183 private practitioners answered to our two calls through the Nemesis website, and through Facebook Nemesis group. We may explain our failure by the fact that we asked not-research trained colleagues to review a specific type of scholarly methodology using only a social media which is mostly used for personal entertainment. We should rather try to organize a workshop to clarify our expectations in face-to-face manner with our colleagues from private practice. This approach was impossible this time due to Covid-19 situation in Belgium.

The main limitation was the use of only one PubMed database, which was free of use from home. Directory of Open access journals (DOAJ) was not selected. DOAJ is a database which excludes closed access articles in any given topic, and therefore which hidden the major issue of pay-walls in science. Barrier of language may also be a bias in our study as only articles in English and French were selected. Russia is an example of developed country with recognized scientific tradition, and with missing data for our research. Russian authors may publish in their own language and in journals not selected in PubMed database.

Finally, the null hypothesis was accepted: dentists from private practice are rarely involved in publications on anatomical variations using CBCT in dentomaxillofacial area. 
- Acknowledgements: We would like to thank Mrs MH Grégoire, Presses universitaires de Louvain (PUL), UCLouvain, Belgium, for figures preparation.

- Funding sources statement: this study does not received any funding.

- Competing interests: Prof R. Olszewski declares competing interests as Editorin-Chief of Nemesis. All other authors declare no conflicts of interest.

- Ethical approval: There was no need for ethical committee approval for this study.

- Informed consent: There was no need for informed consent for this study.

\section{Authors contribution:}

\begin{tabular}{|l|l|}
\hline Author & Contributor role \\
\hline Hebda Aleksandra & $\begin{array}{l}\text { Conceptualization, Methodology, } \\
\text { Resources, Validation, Writing original } \\
\text { draft preparation, Supervision, Writing } \\
\text { review and editing }\end{array}$ \\
\hline Theys Stéphanie & $\begin{array}{l}\text { Validation, Writing original draft } \\
\text { preparation, Writing review and editing }\end{array}$ \\
\hline De Roissart Jean & $\begin{array}{l}|c| \\
\text { Validation, Writing original draft } \\
\text { Preparation, Writing review and editing }\end{array}$ \\
\hline Olszewski Raphael & $\begin{array}{l}\text { Validation, Writing original draft } \\
\text { preparation, Writing review and editing }\end{array}$ \\
\hline & $\begin{array}{l}\text { Conceptualization, Data curation, } \\
\text { Investigation, Methodology, Resources, } \\
\text { Validation, Writing original draft } \\
\text { preparation, Supervision, Writing review } \\
\text { and editing }\end{array}$ \\
\hline
\end{tabular}

\section{References}

1. Olszewski R. Hebda A. Accessibility to the knowledge on anatomical variations from dentomaxillofacial CBCT. Nemesis 2020;10:1-19. DOI: https://doi.org/10.14428/nemesis.v10i1.53063 
400
2. Duruel O, Kulkarni V, Ataman-Duruel ET, Tözüm MD, Tözüm TF. Radio-Morphometric evaluation of greater palatine canal and pterygopalatine fossa component: maxillary anesthetic implications. J Craniofac Surg 2019;30:863-867.

\section{Aytugar E, Özeren C, Lacin N, Veli I, Çene E. Cone-beam computed} tomographic evaluation of accessory mental foramen in a Turkish population. Anat Sci Int 2019;94:257-265.

4. Bahşi İ, Orhan M, Kervancıoğlu P, Yalçın ED. The anatomical and radiological evaluation of the Vidian canal on cone-beam computed tomography images. Eur Arch Otorhinolaryngol 2019;276:1373-1383.

5. Icen $\mathrm{M}$, Orhan $\mathrm{K}$. Cone-beam computed tomography evaluation of the pterygomaxillary fissure and pterygopalatine fossa using 3D rendering programs. Surg Radiol Anat 2019;41:513-522.

6. Bayrak S, Göller Bulut D, Orhan K. Prevalence of anatomical variants in the clivus: fossa navicularis magna, canalis basilaris medianus, and craniopharyngeal canal. Surg Radiol Anat 2019;41:477-483.

7. Ling C, Jiang Q, Ding X. Cone-Beam computed tomography study on morphologic characteristics of the posterior region in hard palate. J Craniofac Surg 2019;30:921-925.

8. Ottersen MK, Abrahamsson AK, Larheim TA, Arvidsson LZ. CBCT characteristics and interpretation challenges of temporomandibular joint osteoarthritis in a hand osteoarthritis cohort. Dentomaxillofac Radiol 2019;48:20180245.

9. Kapoor V, Kumar N, Dahiya K, Sikka R, Sirana P, Singh A. To assess and evaluate the variation of mandibular anatomy using cone beam computed tomography before planning an implant surgery: a population-based retrospective study. J Contemp Dent Pract 2018;19:1381-1385.

10. Rajput BS, Merita S, Parihar AS, Vyas T, Kaur P, Chansoria S. Assessment of lingual concavities in submandibular fossa region in patients requiring dental implants-A cone beam computed tomography study. J Contemp Dent Pract 2018;19:1329-1333.

11. Rusu MC, Măru N, Sava CJ, Săndulescu M, Dincă D. Rare anatomic variation: Giant unilateral concha bullosa superior. Morphologie 2019;103:54-59. 
12. Şimşek Kaya G, Daltaban Ö, Kaya M, Kocabalkan B, Sindel A, Akdağ M. The potential clinical relevance of anatomical structures and variations of the maxillary sinus for planned sinus floor elevation procedures: A retrospective cone beam computed tomography study. Clin Implant Dent Relat Res 2019;21:114-121.

13. Corbella S, Baruffaldi M, Perondi I, Taschieri S. Cone-beam computed tomography investigation of the anatomy of permanent mandibular premolars in a cohort of Caucasians. J Investig Clin Dent 2019;10:e12373.

14. Su CC, Huang RY, Wu YC, Cheng WC, Chiang HS, Chung MP, Cathy Tsai $\mathrm{YW}$, Chung $\mathrm{CH}$, Shieh YS. Detection and location of second mesiobuccal canal in permanent maxillary teeth: A cone-beam computed tomography analysis in a Taiwanese population. Arch Oral Biol 2019;98:108-114.

15. Rodricks D, Phulambrikar T, Singh SK, Gupta A. Evaluation of incidence of mental nerve loop in Central India population using cone beam computed tomography. Indian J Dent Res 2018;29:627-633.

16. Polo CL, Abdelkarim AZ, von Arx T, Lozanoff S. The morphology of the infraorbital nerve and foramen in the presence of an accessory infraorbital foramen. J Craniofac Surg 2019;30:244-253.

17. Aps JKM, Gazdeck LY, Nelson T, Slayton RL, Scott JM. Assessment of the location of the mandibular lingula in pediatric patients using cone beam computed tomography images. J Dent Child (Chic) 2018;85:58-65.

18. Aksoy U, Orhan K. Risk factor in endodontic treatment: topographic evaluation of mandibular posterior teeth and lingual cortical plate using cone beam computed tomography (CT). Med Sci Monit 2018;24:7508-7516.

19. Fontolliet M, Bornstein MM, von Arx T. Characteristics and dimensions of the infraorbital canal: a radiographic analysis using cone beam computed tomography (CBCT). Surg Radiol Anat 2019;41:169-179.

20. Estrela C, Couto GS, Bueno MR, Bueno KG, Estrela LRA, Porto OCL, Diogenes A. Apical foramen position in relation to proximal root surfaces of human permanent teeth determined by using a new cone-beam computed tomographic software. J Endod 2018;44:1741-1748.

21. Martins JNR, Alkhawas MAM, Altaki Z, Bellardini G, Berti L, Boveda C, Chaniotis A, Flynn D, Gonzalez JA, Kottoor J, Marques MS, Monroe A, Ounsi HF, Parashos P, Plotino G, Ragnarsson MF, Aguilar RR, Santiago F, Seedat HC, Vargas W, von Zuben M, Zhang Y, Gu Y, Ginjeira A. Worldwide analyses of maxillary 
first molar second mesiobuccal prevalence: a multicenter cone-beam computed tomographic study. J Endod 2018;44:1641-1649.

22. Saber SEDM, Ahmed MHM, Obeid M, Ahmed HMA. Root and canal morphology of maxillary premolar teeth in an Egyptian subpopulation using two classification systems: a cone beam computed tomography study. Int Endod J 2019;52:267-278.

23. Alqedairi A, Alfawaz H, Al-Dahman Y, Alnassar F, Al-Jebaly A, Alsubait S. Cone-Beam computed tomographic evaluation of root canal morphology of maxillary premolars in a Saudi population. Biomed Res Int 2018;2018:8170620.

24. Ataman-Duruel ET, Duruel O, Turkyilmaz I, Tözüm TF. Anatomic variation of posterior superior alveolar artery: review of literature and case introduction. J Oral Implantol 2019;45:79-85.

25. Rocha BCS, Andrade J, Valerio CS, Manzi FR. Enamel pearl diagnosed by cone beam computed tomography: A clinical case report. Indian J Dent Res 2018;29:517520 .

26. Kavarthapu A, Thamaraiselvan M. Assessing the variation in course and position of inferior alveolar nerve among south Indian population: A cone beam computed tomographic study. Indian J Dent Res 2018;29:405-409.

27. Vieira CL, Veloso SDAR, Lopes FF. Location of the course of the mandibular canal, anterior loop and accessory mental foramen through cone-beam computed tomography. Surg Radiol Anat 2018;40:1411-1417.

28. Yurdabakan ZZ, Okumus O, Pekiner FN. Evaluation of the maxillary third molars and maxillary sinus using cone-beam computed tomography. Niger J Clin Pract 2018;21:1050-1058.

29. Demiralp KÖ, Kurşun-Çakmak EŞ, Bayrak S, Sahin O, Atakan C, Orhan K. Evaluation of anatomical and volumetric characteristics of the nasopalatine canal in anterior dentate and edentulous individuals: a CBCT study. Implant Dent 2018;27:474-479.

30. Bahşi I, Orhan M, Kervancıoğlu P, Yalçın ED, Aktan AM. Anatomical evaluation of nasopalatine canal on cone beam computed tomography images. Folia Morphol (Warsz) 2019;78:153-162.

31. Li YH, Bao SJ, Yang XW, Tian XM, Wei B, Zheng YL. Symmetry of root anatomy and root canal morphology in maxillary premolars analyzed using conebeam computed tomography. Arch Oral Biol 2018;94:84-92. 
32. Saati S, Shokri A, Foroozandeh M, Poorolajal J, Mosleh N. Root morphology and number of canals in mandibular central and lateral incisors using cone beam computed tomography. Braz Dent J 2018;29:239-244.

33. Ayach OA, Hadad R. Correlation between cervical vertebrae volume parameter and the skeletal maturation status. J Contemp Dent Pract 2018;19:662668.

34. Nimigean V, Sîrbu VD, Nimigean VR, Bădiţă DG, Poll A, Moraru SA, Păun DL. Morphological assessment of the mandibular canal trajectory in edentate subjects. Rom J Morphol Embryol 2018;59:235-242.

35. Zheng J, Ni S, Wang Y, Zhang B, Teng Y, Jiang S. Sex determination of Han adults in Northeast China using cone beam computer tomography. Forensic Sci Int 2018;289:450.e1-450.e7.

36. Rostetter C, Hungerbühler A, Blumer M, Rücker M, Wagner M, Stadlinger B, Lübbers HT. Cone beam computed tomography evaluation of the artery in the lateral wall of the maxillary sinus: retrospective analysis of 602 sinuses. Implant Dent 2018;27:434-438.

37. Goyushov S, Tözüm MD, Tözüm TF. Assessment of morphological and anatomical characteristics of mental foramen using cone beam computed tomography. Surg Radiol Anat 2018;40:1133-1139.

38. Ridel AF, Demeter F, Liebenberg J, L'Abbé EN, Vandermeulen D, Oettlé AC. Skeletal dimensions as predictors for the shape of the nose in a South African sample: A cone-beam computed tomography (CBCT) study. Forensic Sci Int 2018;289:18-26.

39. do Carmo Oliveira M, Tedesco TK, Gimenez T, Allegrini S Jr. Analysis of the frequency of visualization of morphological variations in anatomical bone features in the mandibular interforaminal region through cone-beam computed tomography. Surg Radiol Anat 2018;40:1119-1131.

40. Fan L, Yuan K, Niu C, Ma R, Huang Z. A cone-beam computed tomography study of the mesial cervical concavity of maxillary first premolars. Arch Oral Biol 2018;92:79-82.

41. Goller Bulut D, Köse E. Available bone morphology and status of neural structures in the mandibular interforaminal region: three-dimensional analysis of anatomical structures. Surg Radiol Anat 2018;40:1243-1252. 
42. Niu L, Wang J, Yu H, Qiu L. New classification of maxillary sinus contours and its relation to sinus floor elevation surgery. Clin Implant Dent Relat Res 2018;20:493-500.

43. Allam E, Mpofu P, Ghoneima A, Tuceryan M, Kula K. The relationship between hard tissue and soft tissue dimensions of the nose in children: a 3D cone beam computed tomography study. J Forensic Sci 2018;63:1652-1660.

44. de Castro MAA, Barra SG, Vich MOL, Abreu MHG, Mesquita RA. Mandibular canal branching assessed with cone beam computed tomography. Radiol Med 2018;123:601-608.

45. J PC, Marimuthu T, C K, Devadoss P, Kumar SM. Prevalence and measurement of anterior loop of the mandibular canal using CBCT: A cross sectional study. Clin Implant Dent Relat Res 2018;20:531-534.

46. Rao JB, Tatuskar P, Pulla A, Kumar N, Patil SC, Tiwari I. Radiographic assessment of anatomy of nasopalatine canal for dental implant Placement: a cone beam computed tomographic study. J Contemp Dent Pract 2018;19:301-305.

47. Kikuta S, Iwanaga J, Nakamura K, Hino K, Nakamura M, Kusukawa J. The retromolar canals and foramina: radiographic observation and application to oral surgery. Surg Radiol Anat 2018;40:647-652.

48. Liu L, Kang BC, Yoon SJ, Lee JS, Hwang SA. Radiographic features of lingual mandibular bone depression using dental cone beam computed tomography. Dentomaxillofac Radiol 2018;47:20170383.

49. Krohn S, Brockmeyer P, Kubein-Meesenburg D, Kirschneck C, Buergers R. Elongated styloid process in patients with temporomandibular disorders - Is there a link? Ann Anat 2018;217:118-124.

50. Zahedi S, Mostafavi M, Lotfirikan N. Anatomic study of mandibular posterior teeth using cone-beam computed tomography for endodontic surgery. J Endod 2018;44:738-743.

51. Krishnan U, Monsour P, Thaha K, Lalloo R, Moule A. A limited field conebeam computed tomography-based evaluation of the mental foramen, accessory mental foramina, anterior loop, lateral lingual foramen, and lateral lingual canal. $\mathrm{J}$ Endod 2018;44:946-951.

52. Aksoy U, Orhan K. Association between odontogenic conditions and maxillary sinus mucosal thickening: a retrospective CBCT study. Clin Oral Investig 2019;23:123-131. 
53. Bayrak S, Kurşun-Çakmak EŞ, Atakan C, Orhan K. Anatomic study on sphenoidal emissary foramen by using cone-beam computed tomography. J Craniofac Surg 2018;29:e477-e480.

54. Alfawaz H, Alqedairi A, Alkhayyal AK, Almobarak AA, Alhusain MF, Martins JNR. Prevalence of C-shaped canal system in mandibular first and second molars in a Saudi population assessed via cone beam computed tomography: a retrospective study. Clin Oral Investig 2019;23:107-112.

55. Shah NP, Murtadha L, Brown J. Bifurcation of the inferior dental nerve canal: an anatomical study. Br J Oral Maxillofac Surg 2018;56:267-271.

56. Sava CJ, Rusu MC, Săndulescu M, Dincă D. Vertical and sagittal combinations of concha bullosa media and paradoxical middle turbinate. Surg Radiol Anat 2018;40:847-853.

57. Ding X, Suzuki S, Shiga M, Ohbayashi N, Kurabayashi T, Moriyama K.

Evaluation of tongue volume and oral cavity capacity using cone-beam computed tomography. Odontology 2018;106:266-273.

58. Pilloni A, Rotundo R, Gambarini G, Testarelli L, Dell'olmo F. Bone dehiscences and fenestrations of the anterior mandibular facial bone wall: a retrospective cone beam computed tomography study. Minerva Stomatol 2018;67:86-95.

59. Lvovsky A, Bachrach S, Kim HC, Pawar A, Levinzon O, Ben Itzhak J, Solomonov M. Relationship between root apices and the mandibular canal: a conebeam computed tomographic comparison of 3 populations. J Endod 2018;44:555558.

60. Bayrak S, Ustaoğlu G, Demiralp KÖ, Kurşun Çakmak EŞ. Evaluation of the characteristics and association between Schneiderian membrane thickness and nasal septum deviation. J Craniofac Surg 2018;29:683-687.

61. Gümüşok M, Akarslan ZZ, Başman A, Üçok Ö. Evaluation of accessory mental foramina morphology with cone-beam computed tomography. Niger J Clin Pract 2017;20:1550-1554.

62. Martins JNR, Ordinola-Zapata R, Marques D, Francisco H, Caramês J. Differences in root canal system configuration in human permanent teeth within different age groups. Int Endod J 2018;51:931-941.

63. Sanchez-Perez A, Boix-Garcia P, Lopez-Jornet P. Cone-Beam CT assessment of the position of the medial lingual foramen for dental implant placement in the 
anterior symphysis. Implant Dent 2018;27:43-48.

64. Chen YC, Tsai CL, Chen YC, Chen G, Yang SF. A cone-beam computed tomography study of C-shaped root canal systems in mandibular second premolars in a Taiwan Chinese subpopulation. J Formos Med Assoc 2018;117:1086-1092.

65. Haghanifar S, Moudi E, Bijani A, Ghanbarabadi MK. Morphologic assessment of mandibular anterior teeth root canal using CBCT. Acta Med Acad 2017;46:85-93.

66. Borghesi A, Pezzotti S, Nocivelli G, Maroldi R. Five mental foramina in the same mandible: CBCT findings of an unusual anatomical variant. Surg Radiol Anat 2018;40:635-640.

67. Ghandourah AO, Rashad A, Heiland M, Hamzi BM, Friedrich RE. Cone-beam tomographic analysis of canalis sinuosus accessory intraosseous canals in the maxilla. Ger Med Sci 2017;15:Doc20.

68. Aksoy U, Aksoy S, Orhan K. A cone-beam computed tomography study of the anatomical relationships between mandibular teeth and the mandibular canal, with a review of the current literature. Microsc Res Tech 2018;81:308-314.

69. Olczak K, Pawlicka H. The morphology of maxillary first and second molars analyzed by cone-beam computed tomography in a polish population. BMC Med Imaging 2017; 17:68.

70. Bonta H, Carranza N, Gualtieri AF, Rojas MA. Morphological characteristics of the facial bone wall related to the tooth position in the alveolar crest in the maxillary anterior. Acta Odontol Latinoam 2017;30:49-56.

71. Talo Yildirim T, Güncü GN, Colak M, Nares S, Tözüm TF. Evaluation of maxillary sinus septa: a retrospective clinical study with cone beam computerized tomography (CBCT). Eur Rev Med Pharmacol Sci 2017;21:5306-5314.

72. Ketterer MC, Aschendorff A, Arndt S, Hassepass F, Wesarg T, Laszig R, Beck $\mathrm{R}$. The influence of cochlear morphology on the final electrode array position. Eur Arch Otorhinolaryngol 2018;275:385-394.

73. AlTarawneh S, AlHadidi A, Hamdan AA, Shaqman M, Habib E. Assessment of bone dimensions in the anterior maxilla: A cone beam computed tomography study. J Prosthodont 2018;27:321-328.

74. Lim EL, Ngeow WC, Lim D. The implications of different lateral wall thicknesses on surgical access to the maxillary sinus. Braz Oral Res 2017;31:e97. 
75. Studebaker B, Hollender L, Mancl L, Johnson JD, Paranjpe A. The Incidence of second mesiobuccal canals located in maxillary molars with the aid of cone-beam computed tomography. J Endod 2018;44:565-570.

76. Ali IK, Sansare K, Karjodkar FR, Salve P. Cone beam computed tomography assessment of accessory Infraorbital foramen and determination of infraorbital foramen position. J Craniofac Surg 2018;29:e124-e126.

77. Al-Ghurabi ZH, Abdulrazaq SS. Vascular precautions before sinus lift procedure. J Craniofac Surg 2018;29:e116-e118.

78. Gu L, Zhu C, Chen K, Liu X, Tang Z. Anatomic study of the position of the mandibular canal and corresponding mandibular third molar on cone-beam omputed tomography images. Surg Radiol Anat 2018;40:609-614.

79. Wu YC, Cheng WC, Chung MP, Su CC, Weng PW, Cathy Tsai YW, Chiang HS, Yeh HW, Chung CH, Shieh YS, Huang RY. Complicated root canal morphology of mandibular lateral incisors is associated with the presence of distolingual root in mandibular first molars: a cone-beam computed tomographic study in a Taiwanese population. J Endod 2018;44:73-79.

80. Sun R, Cai Y, Yuan Y, Zhao JH. The characteristics of adjacent anatomy of mandibular third molar germs: a CBCT study to assess the risk of extraction. Sci Rep 2017;7:14154.

81. Dagistan S, Miloğlu Ö, Altun O, Umar EK. Retrospective morphometric analysis of the infraorbital foramen with cone beam computed tomography. Niger $\mathbf{J}$ Clin Pract 2017;20:1053-1064.

82. Sun W, Liu A, Gong Y, Shu R, Xie Y. Evaluation of the anastomosis canal in lateral maxillary sinus wall with cone beam computerized tomography: a clinical study. J Oral Implantol 2018;44:5-13.

83. Srebrzyńska-Witek A, Koszowski R, Różyło-Kalinowska I. Relationship between anterior mandibular bone thickness and the angulation of incisors and canines-a CBCT study. Clin Oral Investig 2018;22:1567-1578.

84. Ratanajirasut R, Panichuttra A, Panmekiate S. A cone-beam computed tomographic study of root and canal morphology of maxillary first and second permanent molars in a Thai population. J Endod 2018;44:56-61.

85. Štoković N, Trkulja V, Čuković-Bagić I, Lauc T, Grgurević L. Anatomical variations of the frontal sinus and its relationship with the orbital cavity. Clin Anat 2018;31:576-582. 
86. Zhang Y, Xu H, Wang D, Gu Y, Wang J, Tu S, Qiu X, Zhang F, Luo Y, Xu S, Bai J, Simone G, Zhang G. Assessment of the second mesiobuccal root canal in maxillary first molars: a cone-beam computed tomographic study. J Endod 2017;43:1990-1996.

87. Yildirim TT, Güncü GN, Göksülük D, Tözüm MD, Colak M, Tözüm TF. The effect of demographic and disease variables on Schneiderian membrane thickness and appearance. Oral Surg Oral Med Oral Pathol Oral Radiol 2017;124:568-576.

88. Alam MK, Alhabib S, Alzarea BK, Irshad M, Faruqi S, Sghaireen MG, Patil S, Basri R. 3D CBCT morphometric assessment of mental foramen in Arabic population and global comparison: imperative for invasive and non-invasive procedures in mandible. Acta Odontol Scand 2018;76:98-104.

89. Li Y, Yang X, Zhang B, Wei B, Gong Y. Detection and characterization of the accessory mental foramen using cone-beam computed tomography. Acta Odontol Scand 2018;76:77-85.

90. Rusu MC, Măru N, Săndulescu M, Sava CJ. Rare anatomic variation: true bifid inferior turbinate. Surg Radiol Anat 2018;40:217-220.

91. Yeung AWK, Tanaka R, Khong PL, von Arx T, Bornstein MM. Frequency, location, and association with dental pathology of mucous retention cysts in the maxillary sinus. A radiographic study using cone beam computed tomography (CBCT). Clin Oral Investig 2018;22:1175-1183.

92. Wang Y, Qiu Y, Liu H, He J, Fan X. Quantitative evaluation of palatal bone thickness for the placement of orthodontic miniscrews in adults with different facial types. Saudi Med J 2017;38:1051-1057.

93. Santos AR, Castellucci M, Crusoé-Rebello IM, Sobral MC. Assessing bone thickness in the infrazygomatic crest area aiming the orthodontic miniplates positioning: a tomographic study. Dental Press J Orthod 2017;22:70-76.

94. Zand V, Mokhtari H, Zonouzi HR, Shojaei SN. Root canal morphologies of mesiobuccal roots of maxillary molars using cone beam computed tomography and periapical radiographic techniques in an Iranian population. J Contemp Dent Pract 2017; 18:745-749.

95. Petitjean E, Mavridou A, Li X, Hauben E, Cotti E, Lambrechts P. Multimodular assessment of a calcified extraradicular deposit on the root surfaces of a mandibular molar. Int Endod J 2018;51:375-385.

96. Akbarzadeh N, Aminoshariae A, Khalighinejad N, Palomo JM, Syed A, Kulild JC, Sadeghi G, Mickel A. The Association between the anatomic landmarks of the 
pulp chamber floor and the prevalence of middle mesial canals in mandibular first molars: an in vivo analysis. J Endod 2017;43:1797-1801.

97. Kim SH, Shin SM, Choi YS, Ko CC, Kim SS, Park SB, Son WS, Kim YI. Morphometric analysis of the maxillary root apex positions according to crowding severity. Orthod Craniofac Res 2017;20:202-208.

98. Wang M, Sun Y, Yu Y, Ding X. Evaluation of palatal bone thickness for insertion of orthodontic mini-implants in adults and adolescents. J Craniofac Surg 2017;28:1468-1471.

99. Voon YS, Patil PG. Safe zone in anterior mandible related to the genial tubercle for implant osteotomy in a Chinese-Malaysian population: A CBCT study. J Prosthet Dent 2018;119:568-573.

100. Alhazmi A, Vargas E, Palomo JM, Hans M, Latimer B, Simpson S. Timing and rate of spheno-occipital synchondrosis closure and its relationship to puberty. PLoS One 2017;12:e0183305. Erratum in: PLoS One 2018;13:e191703.

101. Rusu MC, Săndulescu M, Bichir C, Muntianu LAS. Combined anatomical variations: The mylohyoid bridge, retromolar canal and accessory palatine canals branched from the canalis sinuosus. Ann Anat 2017;214:75-79.

102. Muinelo-Lorenzo J, Fernández-Alonso A, Smyth-Chamosa E, SuárezQuintanilla JA, Varela-Mallou J, Suárez-Cunqueiro MM. Predictive factors of the dimensions and location of mental foramen using cone beam computed tomography. PLoS One 2017;12:e0179704.

103. Matsumura T, Ishida $Y$, Kawabe A, Ono T. Quantitative analysis of the relationship between maxillary incisors and the incisive canal by cone-beam computed tomography in an adult Japanese population. Prog Orthod 2017;18:24.

104. Lozano-Carrascal N, Salomó-Coll O, Gehrke SA, Calvo-Guirado JL, Hernández-Alfaro F, Gargallo-Albiol J. Radiological evaluation of maxillary sinus anatomy: A cross-sectional study of 300 patients. Ann Anat 2017;214:1-8.

105. Hiebert BM, Abramovitch K, Rice D, Torabinejad M. Prevalence of second mesiobuccal canals in maxillary first molars detected using cone-beam computed tomography, direct occlusal access, and coronal plane grinding. J Endod 2017;43:1711-1715.

106. Pérez-Heredia M, Ferrer-Luque CM, Bravo M, Castelo-Baz P, Ruíz-Piñón M, Baca P. Cone-beam computed tomographic study of root anatomy and canal configuration of molars in a Spanish population. J Endod 2017;43:1511-1516. 
107. Wanzeler AMV, Renda MDO, de Oliveira Pereira ME, Alves-Junior SM, Tuji FM. Anatomical relation between nasal septum deviation and oropharynx volume in different facial patterns evaluated through cone beam computed tomography. Oral Maxillofac Surg 2017;21:341-346.

108. Ring J, Ring KC. Rare root canal configuration of mandibular second premolar using cone-beam computed tomographic scanning. J Endod. 2017;43:1897-1900.

109. Choi IGG, Duailibi-Neto EF, Beaini TL, da Silva RLB, Chilvarquer I. The frontal sinus cavity exhibits sexual dimorphism in 3D cone-beam CT images and can be used for sex determination. J Forensic Sci 2018;63:692-698.

110. Gopalakrishnan A, Unnikrishna K, Balan A, Haris PS. Use of cone-beam computed tomography in the diagnosis and treatment of an unusual canine abnormality. Sultan Qaboos Univ Med J 2017;17:e238-e240.

111. Atil F, Adisen MZ, Misirlioglu M, Suer BT. Stafne bone cavity complicated by periapical Infection. J Coll Physicians Surg Pak 2016;26:109-110.

112. Wang X, Chen K, Wang S, Tiwari SK, Ye L, Peng L. Relationship between the mental foramen, mandibular canal, and the surgical access line of the mandibular posterior teeth: a cone-beam computed tomographic analysis.

J Endod 2017;43:1262-1266.

113. Scomparin L, Soares MQ, Rubira CM, Yaedú RY, Imada TS, Centurion BS, Tolentino ES, Lauris JR, Rubira-Bullen IR. CBCT location of the fusion between the buccal and lingual cortical in the mandibular ramus: importance to sagittal split osteotomy. Med Oral Patol Oral Cir Bucal 2017;22:e500-e505.

114. Vinothkumar TS, Kandaswamy D, Arathi G, Ramkumar S, Felsypremila G. Endodontic management of dilacerated maxillary central incisor fused to a supernumerary tooth using cone beam computed tomography: an unusual clinical presentation. J Contemp Dent Pract 2017;18:522-526.

115. Jang JK, Kwak SW, Ha JH, Kim HC. Anatomical relationship of maxillary posterior teeth with the sinus floor and buccal cortex. J Oral Rehabil 2017;44:617625 .

116. Zhang P, Wei X. Combined therapy for a rare case of type III dens invaginatus in a mandibular central incisor with a periapical lesion: a case report. J Endod 2017;43:1378-1382.

117. Rojo-Sanchis J, Viña-Almunia J, Peñarrocha-Oltra D, Peñarrocha-Diago M. Facial alveolar bone width at the first and second maxillary premolars in healthy 
patients: a cone beam computed tomography study. J Oral Implantol 2017;43:261 265.

118. Chaniotis A, Filippatos CG. The use of a novel approach for the instrumentation of a cone-beam computed tomography-discernible lateral canal in an unusual maxillary incisor: case report. J Endod 2017;43:1023-1027.

119. Nishihara K, Yoshimine SI, Goto T, Ishihata K, Kume KI, Yoshimura T, Nakamura N, Arasaki A. Topographic analysis of the maxillary premolars relative to the maxillary sinus and the alveolar bone using cone beam computed tomography. Oral Surg Oral Med Oral Pathol Oral Radiol 2017;123:606-612.

120. Farahamnd A, Sarlati F, Eslami S, Ghassemian M, Youssefi N, Jafarzadeh Esfahani B. Evaluation of impacting factors on facial bone thickness in the anterior maxillary region. J Craniofac Surg 2017;28:700-705.

121. Martins JNR, Francisco H, Ordinola-Zapata R. Prevalence of C-shaped configurations in the mandibular first and second premolars: a cone-beam computed tomographic in vivo study. J Endod 2017;43:890-895.

122. Zoya-Farook A, Abhishek P, Shahabadi A. Cone-beam computed tomographic evaluation and endodontic management of a mandibular first premolar with type IX canal configuration: case report. J Endod 2017;43:1207-1213.

123. Sa SC, Melo SL, Melo DP, Freitas DQ, Campos PS. Relationship between articular eminence inclination and alterations of the mandibular condyle: a CBCT study. Braz Oral Res 2017;31:e25.

124. Tilen R, Patcas R, Bornstein MM, Ludwig B, Schätzle M. The nasopalatine canal, a limiting factor for temporary anchorage devices: a cone beam computed tomography data study. Eur J Orthod 2017;39:646-653.

125. Yang XW, Zhang FF, Li YH, Wei B, Gong Y. Characteristics of intrabony nerve canals in mandibular interforaminal region by using cone-beam computed tomography and a recommendation of safe zone for implant and bone harvesting. Clin Implant Dent Relat Res 2017;19:530-538.

126. Pamboo J, Hans MK, Chander S, Sharma K. Endodontic management of maxillary first molar with two palatal canals aided with cone beam computed tomography: a case report. Compend Contin Educ Dent 2017;38:e1-e4.

127. Tan X, Zhang L, Zhou W, Li Y, Ning J, Chen X, Song D, Zhou X, Huang D. Palatal radicular groove morphology of the maxillary incisors: a case series report. J Endod 2017;43:827-833. 
128. Pawar AM, Pawar M, Kfir A, Singh S, Salve P, Thakur B, Neelakantan P. Root canal morphology and variations in mandibular second molar teeth of an Indian population: an in vivo cone-beam computed tomography analysis. Clin Oral Investig 2017;21:2801-2809.

129. Caruso S, Storti E, Nota A, Ehsani S, Gatto R. Temporomandibular joint anatomy assessed by CBCT images. Biomed Res Int 2017;2017:2916953.

130. Goergen MJ, Holton NE, Grünheid T. Morphological interaction between the nasal septum and nasofacial skeleton during human ontogeny. J Anat 2017;230:689700 .

131. Zmysłowska-Polakowska E, Radwański M, Łęski M, Ledzion S, ŁukomskaSzymańska M, Polguj M. The assessment of accessory mental foramen in a selected polish population: a CBCT study. BMC Med Imaging 2017;17:17.

132. Tavelli L, Borgonovo AE, Re D, Maiorana C. Sinus presurgical evaluation: a literature review and a new classification proposal. Minerva Stomatol 2017;66:115131.

133. Mladina R, Antunović R, Cingi C, Bayar Muluk N, Skitarelić N. Sinus septi nasi: anatomical study. Clin Anat 2017;30:312-317.

134. Borgonovo AE, Taschieri S, Vavassori V, Re D, Francetti L, Corbella S. Incidence and characteristics of mandibular accessory canals: A radiographic investigation. J Investig Clin Dent 2017;8.

135. Ko YC, Huang HL, Shen YW, Cai JY, Fuh LJ, Hsu JT. Variations in crestal cortical bone thickness at dental implant sites in different regions of the jawbone. Clin Implant Dent Relat Res 2017;19:440-446.

136. Taleghani F, Tehranchi M, Shahab S, Zohri Z. Prevalence, location, and size of maxillary sinus septa: computed tomography scan analysis. J Contemp Dent Pract. 2017;18:11-15.

137. Sîrbu VD, Perlea P, Nimigean VR, Bădiţă DG, Şerban A, Nimigean V. Morphological assessment of the mandibular canal trajectory in dentate subjects. Rom J Morphol Embryol 2017;58:1401-1408.

138. He P, Truong MK, Adeeb N, Tubbs RS, Iwanaga J. Clinical anatomy and surgical significance of the lingual foramina and their canals. Clin Anat 2017;30:194204. 
139. Parker J, Mol A, Rivera EM, Tawil P. CBCT uses in clinical endodontics: the effect of CBCT on the ability to locate MB2 canals in maxillary molars. Int Endod J 2017;50:1109-1115.

140. Jaitley M, Phulambrikar T, Kode M, Gupta A, Singh SK. Foramen magnum as a tool for sexual dimorphism: A cone beam computed tomography study. Indian J Dent Res 2016;27:458-462.

141. Buyuk SK, Sekerci AE, Benkli YA, Ekizer A. A survey of ponticulus posticus: radiological analysis of atlas in an orthodontic population based on cone-beam computed tomography. Niger J Clin Pract 2017;20:106-110.

142. Gungor E, Aglarci OS, Unal M, Dogan MS, Guven S. Evaluation of mental foramen location in the 10-70 years age range using cone-beam computed tomography. Niger J Clin Pract 2017;20:88-92.

143. Rapado-González O, Suárez-Quintanilla JA, Suárez-Cunqueiro MM. Anatomical variations of the greater palatine canal in cone-beam computed tomography. Surg Radiol Anat 2017;39:717-723.

144. Yasa Y, Ocak A, Bayrakdar IS, Duman SB, Gumussoy I. Morphometric analysis of sella turcica using cone beam computed tomography. J Craniofac Surg 2017;28:e70-e74.

145. Betancourt P, Navarro P, Muñoz G, Fuentes R. Prevalence and location of the secondary mesiobuccal canal in 1,100 maxillary molars using cone beam computed tomography. BMC Med Imaging 2016;16:66.

146. Agbaje JO, de Casteele EV, Salem AS, Anumendem D, Lambrichts I, Politis C. Tracking of the inferior alveolar nerve: its implication in surgical planning. Clin Oral Investig 2017;21:2213-2220.

147. Yasa Y, Bayrakdar IS, Ocak A, Duman SB, Dedeoglu N. Evaluation of sella turcica shape and dimensions in cleft subjects using cone-beam computed tomography. Med Princ Pract 2017;26:280-285.

148. Shemesh A, Levin A, Katzenell V, Itzhak JB, Levinson O, Avraham Z, Solomonov M. C-shaped canals-prevalence and root canal configuration by cone beam computed tomography evaluation in first and second mandibular molars-a cross-sectional study. Clin Oral Investig 2017;21:2039-2044.

149. Kabak SL, Zhuravleva NV, Melnichenko YM, Savrasova NA. Study of the mandibular incisive canal anatomy using cone beam computed tomography. Surg Radiol Anat 2017;39:647-655. 
150. Rodrigues CT, Oliveira-Santos C, Bernardineli N, Duarte MA, Bramante CM, Minotti-Bonfante PG, Ordinola-Zapata R. Prevalence and morphometric analysis of three-rooted mandibular first molars in a Brazilian subpopulation. J Appl Oral Sci 2016;24:535-542.

151. Caputo BV, Noro Filho GA, de Andrade Salgado DM, Moura-Netto C, Giovani EM, Costa C. Evaluation of the root canal morphology of molars by using conebeam computed tomography in a Brazilian population: Part I. J Endod 2016;42:1604-1607.

152. Monsarrat P, Arcaute B, Peters OA, Maury E, Telmon N, Georgelin-Gurgel M, Maret D. Interrelationships in the variability of root canal anatomy among the permanent teeth: a full-mouth approach by cone-beam CT. PLoS One 2016;11:e0165329.

153. Celikten B, Tufenkci P, Aksoy U, Kalender A, Kermeoglu F, Dabaj P, Orhan $\mathrm{K}$. Cone beam CT evaluation of mandibular molar root canal morphology in a Turkish Cypriot population. Clin Oral Investig 2016;20:2221-2226.

154. Güldner C, Diogo I, Bernd E, Dräger S, Mandapathil M, Teymoortash A, Negm H, Wilhelm T. Visualization of anatomy in normal and pathologic middle ears by cone beam CT. Eur Arch Otorhinolaryngol 2017;274:737-742.

155. Falcão CA, Albuquerque VC, Amorim NL, Freitas SA, Santos TC, Matos FT, Ferraz MA. Frequency of the mesiopalatal canal in upper first permanent molars viewed through computed tomography. Acta Odontol Latinoam 2016;29:54-59.

156. Borgonovo AE, Rigaldo F, Maiorana C, Grossi GB, Augusti D, Re D. CBCT evaluation of the tridimensional relationship between impacted lower third molar and the inferior alveolar nerve position. Minerva Stomatol 2017;66:9-19.

157. Tambawala SS, Karjodkar FR, Sansare K, Prakash N, Dora AC. Sexual dimorphism of foramen magnum using cone beam computed tomography. J Forensic Leg Med 2016;44:29-34.

158. Cao D, Zhu L, Chen Y, Xie L, Yan B, Sun Z. Buccally impacted maxillary canines increase the likelihood of root separation in adjacent first premolars. Oral Dis 2017;23:36-41.

159. Xu D, Wang Z, Sun L, Lin Z, Wan L, Li Y, Lin X, Peng W, Zhang Z, Gao Y. Classification of the root position of the maxillary central incisors and its clinical significance in immediate implant placement. Implant Dent 2016;25:520-524.

160. Velasco-Torres M, Padial-Molina M, Alarcón JA, O’Valle F, Catena A, Galindo-Moreno P. Maxillary sinus dimensions with respect to the posterior superior 
alveolar artery decrease with tooth loss. Implant Dent 2016;25:464-470.

161. Villaça-Carvalho MF, Manhães LR Jr, de Moraes ME, Lopes SL. Prevalence of bifid mandibular canals by cone beam computed tomography. Oral Maxillofac Surg 2016;20:289-294.

162. Hiremath H, Agarwal R, Hiremath V, Phulambrikar T. Evaluation of proximity of mandibular molars and second premolar to inferior alveolar nerve canal among central Indians: A cone-beam computed tomographic retrospective study. Indian J Dent Res 2016;27:312-316.

163. Sinanoglu A, Orhan K, Kursun S, Inceoglu B, Oztas B. Evaluation of optic canal and surrounding structures using cone beam computed tomography: considerations for maxillofacial surgery. J Craniofac Surg 2016;27:1327-1330.

164. Hourfar J, Bister D, Lisson JA, Goldbecher C, Ludwig B. Vestibulo-Oral inclination of maxillary and mandibular canines and bicuspids - a CBCT investigation. Head Face Med 2016;12:22.

165. Tolstunov L, Brickeen M, Kamanin V, Susarla SM, Selvi F. Is the angulation of mandibular third molars associated with the thickness of lingual bone? Br J Oral Maxillofac Surg 2016;54:914-919.

166. Friedrich RE, Bruhn M, Lohse C. Cone-beam computed tomography of the orbit and optic canal volumes. J Craniomaxillofac Surg 2016;44:1342-1349.

167. Rodricks D, Gupta A, Phulambrikar T, Singh SK, Sharma BK, Agrawal P. Anatomical and morphological characterization of the nasopalatine canal: a conebeam computed tomography study. Mymensingh Med J 2016;25:349-356.

168. Danesh-Sani SA, Movahed A, ElChaar ES, Chong Chan K, Amintavakoli N. Radiographic evaluation of maxillary sinus lateral wall and posterior superior alveolar artery anatomy: a cone-beam computed tomographic study. Clin Implant Dent Relat Res 2017;19:151-160.

169. Ge ZP, Yang P, Li G, Zhang JZ, Ma XC. Age estimation based on pulp cavity/chamber volume of 13 types of tooth from cone beam computed tomography images. Int J Legal Med 2016;130:1159-1167.

170. Kong N, Hui M, Miao F, Yuan H, Du Y, Chen N. Mandibular incisive canal in Han Chinese using cone beam computed tomography. Int J Oral Maxillofac Surg 2016;45:1142-1146.

171. Zhang D, Chen J, Lan G, Li M, An J, Wen X, Liu L, Deng M. The root canal morphology in mandibular first premolars: a comparative evaluation of cone-beam 
computed tomography and micro-computed tomography. Clin Oral Investig 2017;21:1007-1012.

172. Koivisto T, Chiona D, Milroy LL, McClanahan SB, Ahmad M, Bowles WR. Mandibular canal location: cone-beam computed tomography examination. J Endod 2016;42:1018-1021.

173. He X, Jiang J, Cai W, Pan Y, Yang Y, Zhu K, Zheng Y. Assessment of the appearance, location and morphology of mandibular lingual foramina using cone beam computed tomography. Int Dent J 2016;66:272-279.

174. Han SS, Hwang JJ, Jeong HG. Accessory mental foramina associated with neurovascular bundle in Korean population. Surg Radiol Anat 2016;38:1169-1174.

175. Manhães Júnior LR, Villaça-Carvalho MF, Moraes ME, Lopes SL, Silva MB, Junqueira JL. Location and classification of canalis sinuosus for cone beam computed tomography: avoiding misdiagnosis. Braz Oral Res 2016;30:e49.

176. Chong BS, Gohil K, Pawar R, Makdissi J. Anatomical relationship between mental foramen, mandibular teeth and risk of nerve injury with endodontic treatment. Clin Oral Investig 2017;21:381-387.

177. Estrela C, Nunes CA, Guedes OA, Alencar AH, Estrela CR, Silva RG, Pécora JD, Sousa-Neto MD. Study of anatomical relationship between posterior teeth and maxillary sinus floor in a subpopulation of the Brazilian central region using conebeam computed tomography - Part 2. Braz Dent J 2016;27:9-15.

178. Tian XM, Yang XW, Qian L, Wei B, Gong Y. Analysis of the root and canal morphologies in maxillary first and second molars in a Chinese population using cone-beam computed tomography. J Endod 2016;42:696-701.

179. Ogawa A, Fukuta Y, Nakasato H, Nakasato S. Cone beam computed tomographic evaluation of nutrient canals and foramina in the anterior region of the mandible. Surg Radiol Anat 2016;38:1029-1032.

180. Zhang CY, DeBaz C, Bhandal G, Alli F, Buencamino Francisco MC, Thacker HL, Palomo JM, Palomo L. Buccal bone thickness in the esthetic zone of postmenopausal women: a CBCT analysis. Implant Dent 2016;25:478-484.

181. Jiang YY. Correlation between hyoid bone position and airway dimensions in Chinese adolescents by cone beam computed tomography analysis. Int J Oral Maxillofac Surg 2016;45:914-921. 
182. Kim SR, Lee KM, Cho JH, Hwang HS. Three-dimensional prediction of the human eyeball and canthi for craniofacial reconstruction using cone-beam computed tomography. Forensic Sci Int 2016;261:164.e1-8.

183. Zeng C, Shen Y, Guan X, Wang X, Fan M, Li Y. Rare root canal configuration of bilateral maxillary second molar using cone-beam computed tomographic scanning. J Endod 2016;42:673-677.

184. Sanomiya Ikuta CR, Paes da Silva Ramos Fernandes LM, Poleti ML, Alvares Capelozza AL, Fischer Rubira-Bullen IR. Anatomical study of the posterior mandible: lateral lingual foramina in cone beam computed tomography. Implant Dent 2016;25:247-251.

185. Jayaratne YS, Zwahlen RA. The oropharyngeal airway in young adults with skeletal class II and class III deformities: a 3-D morphometric analysis. PLoS One 2016;11:e0148086.

186. Agrawal PK, Wankhade J, Warhadpande M. A rare case of type III dens invaginatus in a mandibular second premolar and its nonsurgical endodontic management by using cone-beam computed tomography: a case report. J Endod 2016;42:669-672.

187. Orhan K, Misirli M, Aksoy S, Seki U, Hincal E, Ormeci T, Arslan A.

Morphometric analysis of the infraorbital foramen, canal and groove using cone beam CT: considerations for creating artificial organs. Int $\mathrm{J}$ Artif Organs 2016;39:28-36.

188. Martins JN, Mata A, Marques D, Anderson C, Caramês J. Prevalence and characteristics of the maxillary C-shaped molar. J Endod 2016;42:383-389.

189. Blacher J, Van DaHuvel S, Parashar V, Mitchell JC. Variation in location of the mandibular foramen/inferior alveolar nerve complex given anatomic landmarks using cone-beam computed tomographic scans. J Endod 2016;42:393-396.

190. Codari M, Zago M, Guidugli GA, Pucciarelli V, Tartaglia GM, Ottaviani F, Righini S, Sforza C. The nasal septum deviation index (NSDI) based on CBCT data. Dentomaxillofac Radiol 2016;45:20150327.

191. Gamba Tde O, Alves MC, Haiter-Neto F. Mandibular sexual dimorphism analysis in CBCT scans. J Forensic Leg Med 2016;38:106-110.

192. Ge J, Zheng JW, Yang C, Qian WT. Variations in the buccal-lingual alveolar bone thickness of impacted mandibular third molar: our classification and treatment perspectives. Sci Rep 2016;6:16375. 
193. Yilmaz HG, Ayali A. Evaluation of the neurovascular bundle position at the palate with cone beam computed tomography: an observational study. Head Face Med 2015;11:39.

194. Yue W, Kim E. Nonsurgical endodontic management of a molar-incisor malformation-affected mandibular first molar: a case report. J Endod 2016;42:664668.

195. Angelieri F, Franchi L, Cevidanes LH, McNamara JA Jr. Diagnostic performance of skeletal maturity for the assessment of midpalatal suture maturation. Am J Orthod Dentofacial Orthop 2015;148:1010-1016.

196. Măru N, Rusu MC, Săndulescu M. Variant anatomy of nasal turbinates: supreme, superior and middle conchae bullosae, paradoxical superior and inferior turbinates, and middle accessory turbinate. Rom J Morphol Embryol 2015;56:12231226.

197. Estrela C, Bueno MR, Couto GS, Rabelo LE, Alencar AH, Silva RG, Pécora JD, Sousa-Neto MD. Study of root canal anatomy in human permanent teeth in a subpopulation of Brazil's center region using cone-beam computed tomography Part 1. Braz Dent J 2015;26:530-536.

198. Lyra CM, Delai D, Pereira KC, Pereira GM, Pasternak Júnior B, Oliveira CA. Morphology of mesiobuccal root canals of maxillary first molars: a comparison of CBCT scanning and cross-sectioning. Braz Dent J 2015;26:525-529.

199. Miles MS, Parks ET, Eckert GJ, Blanchard SB. Comparative evaluation of mandibular canal visibility on cross-sectional cone-beam CT images: a retrospective study. Dentomaxillofac Radiol 2016;45:20150296.

200. Ozcan G, Sekerci AE, Cantekin K, Aydinbelge M, Dogan S. Evaluation of root canal morphology of human primary molars by using CBCT and comprehensive review of the literature. Acta Odontol Scand 2016;74:250-258.

201. Khojastehpour L, Dehbozorgi M, Tabrizi R, Esfandnia S. Evaluating the anatomical location of the posterior superior alveolar artery in cone beam computed tomography images. Int J Oral Maxillofac Surg 2016;45:354-358.

202. Beshkenadze E, Chipashvili N. Anatomo-morphological features of the root canal system in Georgian population-cone beam computed tomography study.

Georgian Med News 2015;(247):7-14. 
203. Levin A, Shemesh A, Katzenell V, Gottlieb A, Ben Itzhak J, Solomonov M. Use of cone-beam computed tomography during retreatment of a 2-rooted maxillary central incisor: case report of a complex diagnosis and treatment. $\mathrm{J}$ Endod 2015;41:2064-2067.

204. Pereira-Maciel P, Tavares-de-Sousa E, Oliveira-Sales MA.The mandibular incisive canal and its anatomical relationships: a cone beam computed tomography study. Med Oral Patol Oral Cir Bucal 2015;20:e723-728.

205. Muinelo-Lorenzo J, Suárez-Quintanilla JA, Fernández-Alonso A, VarelaMallou J, Suárez-Cunqueiro MM. Anatomical characteristics and visibility of mental foramen and accessory mental foramen: panoramic radiography vs. cone beam CT. Med Oral Patol Oral Cir Bucal 2015;20:e707-714.

206. Monsour P, Huang T. Morphology of the greater palatine grooves of the hard palate: a cone beam computed tomography study. Aust Dent J 2016;61:329-332.

207. Tao J, Wu J, Zhang X. Mandibular condylar morphology for bruxers with different grinding patterns. Cranio 2016;34:219-226.

208. Çakur B, Yaşa Y. Correlation between tinnitus and petrotympanic fissure status among patients with temporomandibular joint dysfunction. J Oral Maxillofac Surg 2016;74:47-52.

209. Özçakır-Tomruk C, Dölekoğlu S, Özkurt-Kayahan Z, İlgüy D. Evaluation of morphology of the nasopalatine canal using cone-beam computed tomography in a subgroup of Turkish adult population. Surg Radiol Anat 2016;38:65-70.

210. Varela-Centelles P, Loira-Gago M, Seoane-Romero JM, Takkouche B, Monteiro L, Seoane J. Detection of the posterior superior alveolar artery in the lateral sinus wall using computed tomography/cone beam computed tomography: a prevalence meta-analysis study and systematic review. Int J Oral Maxillofac Surg 2015;44:1405-1410.

211. Dalmau E, Zamora N, Tarazona B, Gandia JL, Paredes V. A comparative study of the pharyngeal airway space, measured with cone beam computed tomography, between patients with different craniofacial morphologies. J Craniomaxillofac Surg 2015;43:1438-446.

212. Dong H, Deng M, Wang W, Zhang J, Mu J, Zhu G. Sexual dimorphism of the mandible in a contemporary Chinese Han population. Forensic Sci Int 2015;255:9 15 . 
213. Friedrich RE, Laumann F, Zrnc T, Assaf AT. The nasopalatine canal in adults on cone beam computed tomograms-a clinical study and review of the literature. In Vivo 2015;29:467-486.

214. Rapado-González O, Suárez-Quintanilla JA, Otero-Cepeda XL, FernándezAlonso A, Suárez-Cunqueiro MM. Morphometric study of the greater palatine canal: cone-beam computed tomography. Surg Radiol Anat 2015;37:1217-1224.

215. Kolsuz ME, Orhan K, Bilecenoglu B, Sakul BU, Ozturk A. Evaluation of genial tubercle anatomy using cone beam computed tomography. J Oral Sci 2015;57:151-156.

216. Zhang W, Skrypczak A, Weltman R. Anterior maxilla alveolar ridge dimension and morphology measurement by cone beam computerized tomography (CBCT) for immediate implant treatment planning. BMC Oral Health 2015;15:65.

217. Zhang S, Shi X, Liu H. Angulations of anterior teeth with reference to the alveolar bone measured by $\mathrm{CBCT}$ in a Chinese population. Implant Dent 2015;24:397-401.

218. Valente NA. Anatomical considerations on the alveolar antral artery as related to the sinus augmentation surgical procedure. Clin Implant Dent Relat Res 2016;18:1042-1050.

219. Tian J, Liang G, Qi W, Jiang H. Odontogenic cutaneous sinus tract associated with a mandibular second molar having a rare distolingual root: a case report. Head Face Med 2015;11:13.

220. Štoković N, Trkulja V, Dumić-Čule I, Čuković-Bagić I, Lauc T, Vukičević S, Grgurević L. Sphenoid sinus types, dimensions and relationship with surrounding structures. Ann Anat 2016;203:69-76.

221. Carruth P, He J, Benson BW, Schneiderman ED. Analysis of the size and position of the mental foramen using the CS 9000 cone-beam computed tomographic unit. J Endod 2015;41:1032-1036.

222. Rusu MC, Săndulescu M, Ilie OC. Infraorbital canal bilaterally replaced by a lateroantral canal. Surg Radiol Anat 2015;37:1149-1153.

223. Fernández-Alonso A, Suárez-Quintanilla JA, Rapado-González O, SuárezCunqueiro MM. Morphometric differences of nasopalatine canal based on 3D classifications: descriptive analysis on CBCT. Surg Radiol Anat 2015;37:825-833. 
224. Yilmaz HG, Boke F, Ayali A. Cone-beam computed tomography evaluation of the soft tissue thickness and greater palatine foramen location in the palate. J Clin Periodontol 2015;42:458-461.

225. Didilescu AC, Rusu MC, Săndulescu M. A rare case of impacted maxillary first premolar. Surg Radiol Anat 2015;37:1145-1147.

226. Al-koshab M, Nambiar P, John J. Assessment of condyle and glenoid fossa morphology using CBCT in South-East Asians. PLoS One 2015;10:e0121682.

227. Nosrat A, Schneider SC. Endodontic management of a maxillary lateral incisor with 4 root canals and a dens invaginatus tract. J Endod 2015;41:1167-1171.

228. Holmes PB, Wolf BJ, Zhou J. A CBCT atlas of buccal cortical bone thickness in interradicular spaces. Angle Orthod 2015;85:911-919.

229. Kim SY, Kim BS, Kim Y. Mandibular second molar root canal morphology and variants in a Korean subpopulation. Int Endod J 2016;49:136-144.

230. Jiang YY, Xu X, Su HL, Liu DX. Gender-related difference in the upper airway dimensions and hyoid bone position in Chinese Han children and adolescents aged 6-18 years using cone beam computed tomography. Acta Odontol Scand 2015;73:391-400.

231. Perlea P, Nistor CC, Suciu I, Iliescu MG, Iliescu AA. Rare multiple internal root resorption associated with perforation - a case report. Rom J Morphol Embryol 2014;55:1477-1481.

232. Capar ID, Ertas H, Arslan H, Tarim Ertas E.A retrospective comparative study of cone-beam computed tomography versus rendered panoramic images in identifying the presence, types, and characteristics of dens invaginatus in a Turkish population. J Endod 2015;41:473-478.

233. De Angelis D, Gibelli D, Gaudio D, Cipriani Noce F, Guercini N, Varvara G, Sguazza E, Sforza C, Cattaneo C. Sexual dimorphism of canine volume: a pilot study. Leg Med (Tokyo) 2015;17:163-166.

234. Nickenig HJ, Wichmann M, Eitner S, Zöller JE, Kreppel M. Lingual concavities in the mandible: a morphological study using cross-sectional analysis determined by CBCT. J Craniomaxillofac Surg 2015;43:254-259.

235. Newaz ZA, Barghan S, Katkar RA, Bennett JA, Nair MK. Incidental findings of skull-base abnormalities in cone-beam computed tomography scans with 
consultation by maxillofacial radiologists. Am J Orthod Dentofacial Orthop 2015; 147:127-131.

236. Cunha RS, Junaid A, Mello I. Unilateral fusion of a supernumerary tooth to a maxillary permanent lateral incisor: a report of a rare case. J Endod 2015;41:420 423.

237. Sekerci AE, Soylu E, Arikan MP, Aglarci OS. Is there a relationship between the presence of ponticulus posticus and elongated styloid process? Clin Imaging 2015;39:220-224.

238. Bayrakdar IS, Miloglu O, Altun O, Gumussoy I, Durna D, Yilmaz AB. Cone beam computed tomography imaging of ponticulus posticus: prevalence, characteristics, and a review of the literature. Oral Surg Oral Med Oral Pathol Oral Radiol 2014;118:e210-219.

239. Friedlander AH, Liebeskind DS, Tran HQ, Mallya SM. What are the potential implications of identifying intracranial internal carotid artery atherosclerotic lesions on cone-beam computed tomography? A systematic review and illustrative case studies. J Oral Maxillofac Surg 2014;72:2167-2177.

240. López Jornet P, Boix P, Sanchez Perez A, Boracchia A. Morphological characterization of the anterior palatine region using cone beam computed tomography. Clin Implant Dent Relat Res 2015;17:e459-464.

241. Huang YD, Wu J, Sheu RJ, Chen MH, Chien DL, Huang YT, Huang CC, Chen YJ. Evaluation of the root and root canal systems of mandibular first premolars in northern Taiwanese patients using cone-beam computed tomography. J Formos Med Assoc 2015;114:1129-1134.

242. Sabir H, Kumbhare S, Rout P. Evaluation of ponticulus posticus on digital lateral cephalograms and cone beam computed tomography in patients with migraine and healthy individuals: a comparative study. Oral Surg Oral Med Oral Pathol Oral Radiol 2014;118:348-354.

243. Chong BS, Quinn A, Pawar RR, Makdissi J, Sidhu SK. The anatomical relationship between the roots of mandibular second molars and the inferior alveolar nerve. Int Endod J 2015;48:549-555.

244. Han T, Ma Y, Yang L, Chen X, Zhang X, Wang Y. A study of the root canal morphology of mandibular anterior teeth using cone-beam computed tomography in a Chinese subpopulation. J Endod 2014;40:1309-1314. 
245. Acar B, Kamburoğlu K. Morphological and volumetric evaluation of the nasopalatinal canal in a Turkish population using cone-beam computed tomography. Surg Radiol Anat 2015;37:259-265.

246. Çağlayan F, Sümbüllü MA, Miloğlu Ö, Akgül HM. Are all soft tissue calcifications detected by cone-beam computed tomography in the submandibular region sialoliths? J Oral Maxillofac Surg 2014;72:1531.

247. Mahdian M, Moghaddam EJ, Alzahrani A, Rengasamy K, Tadinada A. Calcification of the stylohyoid ligament in panoramic radiography and cone beam computed tomography among patients referred for dental implant treatment planning. Implant Dent 2014;23:508-513.

248. Miles DA, Danforth RA. Reporting findings in the cone beam computed tomography volume. Dent Clin North Am 2014;58:687-709.

249. Parks ET. Cone beam computed tomography for the nasal cavity and paranasal sinuses. Dent Clin North Am 2014;58:627-651.

250. Angelopoulos C. Anatomy of the maxillofacial region in the three planes of section. Dent Clin North Am 2014;58:497-521.

251. Nascimento HA, Visconti MA, Macedo Pde T, Haiter-Neto F, Freitas DQ. Evaluation of the zygomatic bone by cone beam computed tomography. Surg Radiol Anat 2015;37:55-60.

252. Sinanoglu A, Helvacioglu-Yigit D. Analysis of C-shaped canals by panoramic radiography and cone-beam computed tomography: root-type specificity by longitudinal distribution. J Endod 2014;40:917-921.

253. Shiki K, Tanaka T, Kito S, Wakasugi-Sato N, Matsumoto-Takeda S, Oda M, Nishimura S, Morimoto Y. The significance of cone beam computed tomography for the visualization of anatomical variations and lesions in the maxillary sinus for patients hoping to have dental implant-supported maxillary restorations in a private dental office in Japan. Head Face Med 2014;10:20.

254. Ok E, Güngör E, Colak M, Altunsoy M, Nur BG, Ağlarci OS. Evaluation of the relationship between the maxillary posterior teeth and the sinus floor using conebeam computed tomography. Surg Radiol Anat 2014;36:907-914.

255. Ok E, Altunsoy M, Nur BG, Aglarci OS, Çolak M, Güngör E. A cone-beam computed tomography study of root canal morphology of maxillary and mandibular premolars in a Turkish population. Acta Odontol Scand 2014;72:701-706. 
256. Sekerci AE, Sisman Y, Payveren MA. Evaluation of location and dimensions of mandibular lingual foramina using cone-beam computed tomography. Surg Radiol Anat 2014;36:857-864.

257. Nicolielo LF, Van Dessel J, Jacobs R, Martens W, Lambrichts I, Rubira-Bullen IR. Presurgical CBCT assessment of maxillary neurovascularization in relation to maxillary sinus augmentation procedures and posterior implant placement. Surg Radiol Anat 2014;36:915-924.

258. Vier-Pelisser FV, Morgental RD, Fritscher G, Ghisi AC, Borba MG, Scarparo RK. Management of type III dens invaginatus in a mandibular premolar: a case report. Braz Dent J 2014;25:73-78.

259. Sekerci AE, Cantekin K, Aydinbelge M. Cone beam computed tomographic analysis of neurovascular anatomical variations other than the nasopalatine canal in the anterior maxilla in a pediatric population. Surg Radiol Anat 2015;37:181-186.

260. Muinelo-Lorenzo J, Suárez-Quintanilla JA, Fernández-Alonso A, MarsillasRascado S, Suárez-Cunqueiro MM. Descriptive study of the bifid mandibular canals and retromolar foramina: cone beam CT vs panoramic radiography. Dentomaxillofac Radiol 2014;43:20140090.

261. Park JB, Lee JE, Kim K, Yoo JT, Kim Y, Kook YA, Ko Y. The thickness of alveolar bone at the mandibular canine and premolar teeth in normal occlusion. $\mathrm{J}$ Craniofac Surg 2014;25:1115-1119.

262. Wanzeler AM, Marinho CG, Alves Junior SM, Manzi FR, Tuji FM.

Anatomical study of the canalis sinuosus in 100 cone beam computed tomography examinations. Oral Maxillofac Surg 2015;19:49-53.

263. Fernández-Alonso A, Suárez-Quintanilla JA, Muinelo-Lorenzo J, Bornstein MM, Blanco-Carrión A, Suárez-Cunqueiro MM. Three-dimensional study of nasopalatine canal morphology: a descriptive retrospective analysis using conebeam computed tomography. Surg Radiol Anat 2014;36:895-905.

264. Steier L, Steier G, Doğramaci EJ, Rossi-Fedele G. Maxillary sinus unilateral aplasia as an incidental finding following cone-beam computed (volumetric)

tomography. Aust Endod J 2014;40:26-31.

265. Eshak M, Brooks S, Abdel-Wahed N, Edwards PC. Cone beam CT evaluation of the presence of anatomic accessory canals in the jaws. Dentomaxillofac Radiol 2014;43:20130259. 
266. Lea C, Deblinger J, Machado R, Nogueira Leal Silva EJ, Vansan LP. Maxillary premolar with 4 separate canals. J Endod 2014;40:591-593.

267. Sekerci AE, Buyuk SK, Cantekin K. Cone-beam computed tomographic analysis of the morphological characterization of the nasopalatine canal in a pediatric population. Surg Radiol Anat 2014;36:925-932.

268. İlgüy D, İlgüy M, Ersan N, Dölekoğlu S, Fişekçioğlu E. Measurements of the foramen magnum and mandible in relation to sex using CBCT. J Forensic Sci 2014;59:601-605.

269. Filo K, Schneider T, Locher MC, Kruse AL, Lübbers HT. The inferior alveolar nerve's loop at the mental foramen and its implications for surgery. J Am Dent Assoc 2014;145:260-269.

270. Arslan H, Ertas ET, Topçuoğlu HS, Şekerci AE, Atici MY, Ertas H, Demirbuğa S. Radicular grooves of maxillary anterior teeth in a Turkish population: a conebeam computed tomographic study. Arch Oral Biol 2014;59:297-301.

271. Kurt H, Orhan K, Aksoy S, Kursun S, Akbulut N, Bilecenoglu B. Evaluation of the superior semicircular canal morphology using cone beam computed tomography: a possible correlation for temporomandibular joint symptoms. Oral Surg Oral Med Oral Pathol Oral Radiol 2014;117:e280-288.

272. Jadhav AB, Fellows D, Hand AR, Tadinada A, Lurie AG. Classification and volumetric analysis of temporal bone pneumatization using cone beam computed tomography. Oral Surg Oral Med Oral Pathol Oral Radiol 2014;117:376-384.

273. Oztunç H, Evlice B, Tatli U, Evlice A. Cone-beam computed tomographic evaluation of styloid process: a retrospective study of 208 patients with orofacial pain. Head Face Med 2014;10:5.

274. Lin Z, Hu Q, Wang T, Ge J, Liu S, Zhu M, Wen S. Use of CBCT to investigate the root canal morphology of mandibular incisors. Surg Radiol Anat 2014;36:877882 .

275. Sekerci AE, Cantekin K, Aydinbelge M. Cone beam computed tomographic analysis of the shape, height, and location of the mandibular lingula in a population of children. Biomed Res Int 2013;2013:825453.

276. Etoz M, Sisman Y. Evaluation of the nasopalatine canal and variations with cone-beam computed tomography. Surg Radiol Anat 2014;36:805-812.

277. Sahman H, Sekerci AE, Ertas ET. Lateral lingual vascular canals of the 
mandible: a CBCT study of 500 cases. Surg Radiol Anat 2014;36:865-870.

278. Badole GP, Warhadpande MM, Shenoi PR, Lachure C, Badole SG. A rare root canal configuration of bilateral maxillary first molar with 7 root canals diagnosed using cone-beam computed tomographic scanning: a case report. J Endod 2014;40:296-301.

279. Silva EJ, Nejaim Y, Silva AI, Haiter-Neto F, Zaia AA, Cohenca N. Evaluation of root canal configuration of maxillary molars in a Brazilian population using conebeam computed tomographic imaging: an in vivo study. J Endod 2014;40:173-176.

280. Mossaz J, Kloukos D, Pandis N, Suter VG, Katsaros C, Bornstein MM. Morphologic characteristics, location, and associated complications of maxillary and mandibular supernumerary teeth as evaluated using cone beam computed tomography. Eur J Orthod 2014;36:708-718.

281. Cantín M, Fonseca GM. Dens invaginatus in an impacted mesiodens: a morphological study. Rom J Morphol Embryol 2013;54(3 Suppl):879-884.

282. Perlea P, Nistor CC, Toma C, Dimitriu B. Endodontic configuration of the lower incisors in a Romanian population: a radiological study. Rom J Morphol Embryol 2013;54(3 Suppl):775-778.

283. Gaur A, Trivedi HP, Gupta M, Sharma A, Likhyani L, Agarwal M. Mandibular first molar with Vertucci type I canal confguration diagnosed with the help of cone beam computed tomography: a rare case report. J Contemp Dent Pract 2014;15:784787.

284. Correr GM, Iwanko D, Leonardi DP, Ulbrich LM, Araújo MR, Deliberador TM. Classification of bifid mandibular canals using cone beam computed tomography. Braz Oral Res 2013;27:510-516.

285. Leite GM, Lana JP, de Carvalho Machado V, Manzi FR, Souza PE, Horta MC. Anatomic variations and lesions of the mandibular canal detected by cone beam computed tomography. Surg Radiol Anat 2014;36:795-804.

286. Paes da Silva Ramos Fernandes LM, Rice D, Ordinola-Zapata R, Alvares Capelozza AL, Bramante CM, Jaramillo D, Christensen H. Detection of various anatomic patterns of root canals in mandibular incisors using digital periapical radiography, 3 cone-beam computed tomographic scanners, and micro-computed tomographic imaging. J Endod 2014;40:42-45.

287. von Arx T, Friedli M, Sendi P, Lozanoff S, Bornstein MM. Location and 
dimensions of the mental foramen: a radiographic analysis by using cone-beam computed tomography. J Endod 2013;39:1522-1528.

288. Kim SY, Kim BS, Woo J, Kim Y. Morphology of mandibular first molars analyzed by cone-beam computed tomography in a Korean population: variations in the number of roots and canals. J Endod 2013;39:1516-1521.

289. Delilbasi C, Orhan K, Icen M, Aksoy S, Horasan S, Kenan Kose S. Evaluation of articular eminence pneumatization using cone beam computed tomography. Minerva Stomatol 2013;62:349-354.

290. Ilgüy D, Ilgüy M, Dolekoglu S, Fisekcioglu E. Evaluation of the posterior superior alveolar artery and the maxillary sinus with CBCT. Braz Oral Res 2013;27:431-437.

291. Shin Y, Kim Y, Roh BD. Maxillary first molar with an O-shaped root morphology: report of a case. Int J Oral Sci 2013;5:242-244.

292. Mathew R, Omami G, Hand A, Fellows D, Lurie A. Cone beam CT analysis of Haller cells: prevalence and clinical significance. Dentomaxillofac Radiol 2013;42:20130055.

293. Yang R, Yang C, Liu Y, Hu Y, Zou J. Evaluate root and canal morphology of primary mandibular second molars in Chinese individuals by using cone-beam computed tomography. J Formos Med Assoc 2013;112:390-395.

294. Kato H. Non-surgical endodontic treatment for dens invaginatus type III using cone beam computed tomography and dental operating microscope: a case report. Bull Tokyo Dent Coll 2013;54:103-108.

295. Orhan AI, Orhan K, Aksoy S, Ozgül O, Horasan S, Arslan A, Kocyigit D. Evaluation of perimandibular neurovascularization with accessory mental foramina using cone-beam computed tomography in children. J Craniofac Surg 2013;24:e365369.

296. Ikuta CR, Cardoso CL, Ferreira-Júnior O, Lauris JR, Souza PH, Rubira-Bullen IR. Position of the greater palatine foramen: an anatomical study through cone beam computed tomography images. Surg Radiol Anat 2013;35:837-842.

297. Silva EJ, Nejaim Y, Silva AV, Haiter-Neto F, Cohenca N. Evaluation of root canal configuration of mandibular molars in a Brazilian population by using conebeam computed tomography: an in vivo study. J Endod 2013;39:849-852. 
298. de Souza Tolentino E, Silva PA, Pagin O, Centurion BS, Molin SK, de Souza Tolentino L. Uncommon trajectory variations of the mandibular canal and of the mandibular incisive canal: case report. Surg Radiol Anat 2013;35:857-861.

299. Oettlé AC, Fourie J, Human-Baron R, van Zyl AW. The midline mandibular lingual canal: importance in implant surgery. Clin Implant Dent Relat Res 2015;17:93-101.

300. Reis AG, Grazziotin-Soares R, Barletta FB, Fontanella VR, Mahl CR. Second canal in mesiobuccal root of maxillary molars is correlated with root third and patient age: a cone-beam computed tomographic study. J Endod 2013;39:588-592.

301. von Arx T, Lozanoff S, Sendi P, Bornstein MM. Assessment of bone channels other than the nasopalatine canal in the anterior maxilla using limited cone beam computed tomography. Surg Radiol Anat 2013;35:783-790.

302. Drage N, Rogers S, Greenall C, Playle R. Incidental findings on cone beam computed tomography in orthodontic patients. J Orthod 2013;40:29-37.

303. Demirbuga S, Sekerci AE, Dinçer AN, Cayabatmaz M, Zorba YO. Use of cone-beam computed tomography to evaluate root and canal morphology of mandibular first and second molars in Turkish individuals. Med Oral Patol Oral Cir Bucal 2013;18:e737-744.

304. Sonnesen L, Jensen KE, Petersson AR, Petri N, Berg S, Svanholt P. Cervical vertebral column morphology in patients with obstructive sleep apnoea assessed using lateral cephalograms and cone beam CT. A comparative study. Dentomaxillofac Radiol 2013;42:20130060.

305. Xu GZ, Yang C, Fan XD, Yu CQ, Cai XY, Wang Y, He D. Anatomic relationship between impacted third mandibular molar and the mandibular canal as the risk factor of inferior alveolar nerve injury. $\mathrm{Br} \mathrm{J}$ Oral Maxillofac Surg 2013;51:e215-219.

306. Patcas R, Tausch D, Pandis N, Manestar M, Ullrich O, Karlo CA, Peltomäki T, Kellenberger CJ. Illusions of fusions: assessing cervical vertebral fusion on lateral cephalograms, multidetector computed tomographs, and cone-beam computed tomographs. Am J Orthod Dentofacial Orthop 2013;143:213-220.

307. Anatomical differences in lower third molars visualized by $2 \mathrm{D}$ and $3 \mathrm{D}$ X-ray imaging: clinical outcomes after extraction. Jun SH, Kim CH, Ahn JS, Padwa BL, Kwon JJ. Int J Oral Maxillofac Surg 2013;42:489-496. 
308. Han M, Wang RY, Liu H, Zhu XJ, Wei FL, Lv T, Wang NN, Hu LH, Li GJ, Liu DX, Wang CL.Association between mandibular posterior alveolar morphology and growth pattern in a Chinese population with normal occlusion. J Zhejiang Univ Sci B 2013;14:25-32.

309. Ladeira DB, Barbosa GL, Nascimento MC, Cruz AD, Freitas DQ, Almeida SM. Prevalence and characteristics of pneumatization of the temporal bone evaluated by cone beam computed tomography. Int J Oral Maxillofac Surg 2013;42:771-775.

310. Sharma A, Sood PB, Singh A, Sachdeva S. Management of a rare case of impacted primary central incisors in a 3-year-old child. J Indian Soc Pedod Prev Dent 2012;30:271-274.

311. Liang RZ, Wu JT, Wu YN, Smales RJ, Hu M, Yu JH, Zhang GD. Bilateral maxillary fused second and third molars: a rare occurrence. Int $\mathrm{J}$ Oral Sci 2012;4:231-234.

312. Imada TS, Fernandes LM, Centurion BS, de Oliveira-Santos C, Honório HM, Rubira-Bullen IR. Accessory mental foramina: prevalence, position and diameter assessed by cone-beam computed tomography and digital panoramic radiographs. Clin Oral Implants Res 2014;25:e94-99.

313. Han X, Yang H, Li G, Yang L, Tian C, Wang Y. A study of the distobuccal root canal orifice of the maxillary second molars in Chinese individuals evaluated by cone-beam computed tomographyJ Appl Oral Sci 2012;20:563-567.

314. Kfir A, Telishevsky-Strauss Y, Leitner A, Metzger Z. The diagnosis and conservative treatment of a complex type 3 dens invaginatus using cone beam computed tomography (CBCT) and 3D plastic models. Int Endod J 2013;46:275288 .

315. Bernades-Mayordomo R, Guijarro-Martínez R, Hernández-Alfaro F. Volumetric CBCT analysis of the palatine process of the anterior maxilla: a potential source for bone grafts. Int J Oral Maxillofac Surg 2013;42:406-410.

316. Marca C, Dummer PM, Bryant S, Vier-Pelisser FV, Só MV, Fontanella V, Dutra VD, de Figueiredo JA. Three-rooted premolar analyzed by high-resolution and cone beam CT. Clin Oral Investig 2013;17:1535-1540.

317. Rege IC, Sousa TO, Leles CR, Mendonça EF. Occurrence of maxillary sinus abnormalities detected by cone beam CT in asymptomatic patients. BMC Oral Health $2012 ; 12: 30$ 
318. Orhan K, Kusakci Seker B, Aksoy S, Bayindir H, Berberoğlu A, Seker E. Cone beam CT evaluation of maxillary sinus septa prevalence, height, location and morphology in children and an adult population. Med Princ Pract 2013;22:47-53.

319. Baratto-Filho F, Leonardi DP, Crozeta BM, Baratto SP, Campos EA, Tomazinho FS, Deliberador TM. The challenges of treating a fused tooth. Braz Dent J 2012;23:256-262.

320. Castro IO, Alencar AH, Valladares-Neto J, Estrela C. Apical root resorption due to orthodontic treatment detected by cone beam computed tomography. Angle Orthod 2013;83:196-203.

321. Lizio G, Pelliccioni GA, Ghigi G, Fanelli A, Marchetti C. Radiographic assessment of the mandibular retromolar canal using cone-beam computed tomography. Acta Odontol Scand 2013;71:650-655.

322. Narayana P, Hartwell GR, Wallace R, Nair UP. Endodontic clinical management of a dens invaginatus case by using a unique treatment approach: a case report. J Endod 2012;38:1145-1148.

323. Kim Y, Lee SJ, Woo J. Morphology of maxillary first and second molars analyzed by cone-beam computed tomography in a korean population: variations in the number of roots and canals and the incidence of fusion. J Endod 2012;38:10631068 .

324. Abella F, Patel S, Durán-Sindreu F, Mercadé M, Roig M. Mandibular first molars with disto-lingual roots: review and clinical management. Int Endod J 2012;45:963-978.

325. Chen JC, Lin LM, Geist JR, Chen JY, Chen CH, Chen YK. A retrospective comparison of the location and diameter of the inferior alveolar canal at the mental foramen and length of the anterior loop between American and Taiwanese cohorts using CBCT. Surg Radiol Anat 2013;35:11-18.

326. de Oliveira-Santos C, Rubira-Bullen IR, Monteiro SA, León JE, Jacobs R. Neurovascular anatomical variations in the anterior palate observed on CBCT images. Clin Oral Implants Res 2013;24:1044-1048.

327. Tian YY, Guo B, Zhang R, Yu X, Wang H, Hu T, Dummer PM. Root and canal morphology of maxillary first premolars in a Chinese subpopulation evaluated using cone-beam computed tomography. Int Endod J 2012;45:996-1003.

328. Tozoglu U, Caglayan F, Harorli A. Foramen tympanicum or foramen of Huschke: anatomical cone beam CT study. Dentomaxillofac Radiol 2012;41:294297. 
329. Güldner C, Zimmermann AP, Diogo I, Werner JA, Teymoortash A. Agedependent differences of the anterior skull base. Int J Pediatr Otorhinolaryngol 2012;76:822-828.

330. Seo DG, Gu Y, Yi YA, Lee SJ, Jeong JS, Lee Y, Chang SW, Lee JK, Park W, Kim KD, Kum KY. A biometric study of C-shaped root canal systems in mandibular second molars using cone-beam computed tomography. Int Endod J 2012;45:807814.

331. Barghan S, Tetradis S, Mallya S. Application of cone beam computed tomography for assessment of the temporomandibular joints. Aust Dent J 2012;57 Suppl 1:109-118.

332. Güldner C, Pistorius SM, Diogo I, Bien S, Sesterhenn A, Werner JA. Analysis of pneumatization and neurovascular structures of the sphenoid sinus using conebeam tomography (CBT). Acta Radiol 2012;53:214-219.

333. Marquezan M, Nojima LI, Freitas AO, Baratieri C, Alves Júnior M, Nojima Mda C, Araújo MT. Tomographic mapping of the hard palate and overlying mucosa. Braz Oral Res 2012;26:36-42.

334. Neves FS, Crusoé-Souza M, Franco LC, Caria PH, Bonfim-Almeida P, CrusoéRebello I. Canalis sinuosus: a rare anatomical variation. Surg Radiol Anat 2012;34:563-566.

335. von Arx T, Hänni A, Sendi P, Buser D, Bornstein MM. Radiographic study of the mandibular retromolar canal: an anatomic structure with clinical importance. J Endod 2011;37:1630-1635.

336. Rosano G, Gaudy JF, Chaumanet G, Del Fabbro M, Taschieri S. [Maxillary sinus septa. Prevalence and anatomy]. Rev Stomatol Chir Maxillofac 2012;113:3235 .

337. Vier-Pelisser FV, Pelisser A, Recuero LC, Só MV, Borba MG, Figueiredo JA. Use of cone beam computed tomography in the diagnosis, planning and follow up of a type III dens invaginatus case. Int Endod J 2012;45:198-208.

338. Babiuc I, Tărlungeanu I, Păuna M. Cone beam computed tomography observations of the lingual foramina and their bony canals in the median region of the mandible. Rom J Morphol Embryol 2011;52:827-829.

339. Kaneko T, Sakaue H, Okiji T, Suda H. Clinical management of dens invaginatus in a maxillary lateral incisor with the aid of cone-beam computed tomography--a case report. Dent Traumatol 2011;27:478-483. 
340. Uysal T, Yagci A, Ucar FI, Veli I, Ozer T. Cone-beam computed tomography evaluation of relationship between tongue volume and lower incisor irregularity. Eur J Orthod 2013;35:555-562.

341. Mizbah K, Gerlach N, Maal TJ, Bergé SJ, Meijer GJ. The clinical relevance of bifid and trifid mandibular canals. Oral Maxillofac Surg 2012;16:147-151.

342. Abella F, Mercadé M, Duran-Sindreu F, Roig M. Managing severe curvature of radix entomolaris: three-dimensional analysis with cone beam computed tomography. Int Endod J 2011;44:876-885.

343. Zhang R, Wang H, Tian YY, Yu X, Hu T, Dummer PM. Use of cone-beam computed tomography to evaluate root and canal morphology of mandibular molars in Chinese individuals. Int Endod J 2011;44:990-999.

344. Oliveira-Santos C, Capelozza AL, Dezzoti MS, Fischer CM, Poleti ML, Rubira-Bullen IR. Visibility of the mandibular canal on CBCT cross-sectional images. J Appl Oral Sci 2011;19:240-243.

345. Orhan K, Sakul BU, Oz U, Bilecenoglu B. Evaluation of the pterygoid hamulus morphology using cone beam computed tomography. Oral Surg Oral Med Oral Pathol Oral Radiol Endod 2011;112:e48-55.

346. Zheng Q, Zhang L, Zhou X, Wang Q, Wang Y, Tang L, Song F, Huang D. Cshaped root canal system in mandibular second molars in a Chinese population evaluated by cone-beam computed tomography. Int Endod J 2011;44:857-862.

347. Swasty D, Lee J, Huang JC, Maki K, Gansky SA, Hatcher D, Miller AJ. Crosssectional human mandibular morphology as assessed in vivo by cone-beam computed tomography in patients with different vertical facial dimensions. Am $\mathrm{J}$ Orthod Dentofacial Orthop 2011;139:e377-389.

348. Kottoor J, Velmurugan N, Ballal S, Roy A. Four-rooted maxillary first molar having $\mathrm{C}$-shaped palatal root canal morphology evaluated using cone-beam computerized tomography: a case report. Oral Surg Oral Med Oral Pathol Oral Radiol Endod 2011;111:e41-45.

349. Lee JH, Kim KD, Lee JK, Park W, Jeong JS, Lee Y, Gu Y, Chang SW, Son WJ, Lee WC, Baek SH, Bae KS, Kum KY. Mesiobuccal root canal anatomy of Korean maxillary first and second molars by cone-beam computed tomography. Oral Surg Oral Med Oral Pathol Oral Radiol Endod 2011;111:785-791.

350. Suter VG, Sendi P, Reichart PA, Bornstein MM. The nasopalatine duct cyst: an analysis of the relation between clinical symptoms, cyst dimensions, and 
nvolvement of neighboring anatomical structures using cone beam computed tomography. J Oral Maxillofac Surg 2011;69:2595-2603.

351. da Silva Ramos Fernandes LM, Capelozza AL, Rubira-Bullen IR. Absence and hypoplasia of the mental foramen detected in CBCT images: a case report. Surg Radiol Anat 2011;33:731-734.

352. Kim SY, Choi SC, Chung YJ. Management of the fused permanent upper lateral incisor: a case report. Oral Surg Oral Med Oral Pathol Oral Radiol Endod 2011;111:649-652.

353. Kovisto T, Ahmad M, Bowles WR. Proximity of the mandibular canal to the tooth apex. J Endod 2011;37:311-315.

354. Durack C, Patel S. The use of cone beam computed tomography in the management of dens invaginatus affecting a strategic tooth in a patient affected by hypodontia: a case report. Int Endod J 2011;44:474-483.

355. Yamada T, Ishihama K, Yasuda K, Hasumi-Nakayama Y, Ito K, Yamaoka M, Furusawa K. Inferior alveolar nerve canal and branches detected with dental cone beam computed tomography in lower third molar region. J Oral Maxillofac Surg 2011;69:1278-1282.

356. Bebnowski D, Hänggi MP, Markic G, Roos M, Peltomäki T. Cervical vertebrae anomalies in subjects with Class II malocclusion assessed by lateral cephalogram and cone beam computed tomography. Eur J Orthod 2012;34:226-231.

357. Rogers SA, Drage N, Durning P. Incidental findings arising with cone beam computed tomography imaging of the orthodontic patient. Angle Orthod 2011;81:350-355.

358. Orhan K, Aksoy S, Bilecenoglu B, Sakul BU, Paksoy CS. Evaluation of bifid mandibular canals with cone-beam computed tomography in a Turkish adult population: a retrospective study. Surg Radiol Anat 2011;33:501-507.

359. Oliveira-Santos C, Souza PH, De Azambuja Berti-Couto S, Stinkens L, Moyaert K, Van Assche N, Jacobs R. Characterisation of additional mental foramina through cone beam computed tomography. J Oral Rehabil 2011;38:595-600.

360. Zhang R, Yang H, Yu X, Wang H, Hu T, Dummer PM. Use of CBCT to identify the morphology of maxillary permanent molar teeth in a Chinese subpopulation. Int Endod J 2011;44:162-169.

361. Chan HL, Brooks SL, Fu JH, Yeh CY, Rudek I, Wang HL. Cross-sectional analysis of the mandibular lingual concavity using cone beam computed 
tomography. Clin Oral Implants Res 2011;22:201-206.

362. Bornstein MM, Balsiger R, Sendi P, von Arx T. Morphology of the nasopalatine canal and dental implant surgery: a radiographic analysis of 100 consecutive patients using limited cone-beam computed tomography. Clin Oral Implants Res 2011;22:295-301.

363. Krithikadatta J, Kottoor J, Karumaran CS, Rajan G. Mandibular first molar having an unusual mesial root canal morphology with contradictory cone-beam computed tomography findings: a case report. J Endod 2010;36:1712-1716.

364. Neelakantan P, Subbarao C, Ahuja R, Subbarao CV, Gutmann JL. Cone-beam computed tomography study of root and canal morphology of maxillary first and second molars in an Indian population. J Endod 2010;36:1622-1627.

365. Fuakami K, Shiozaki K, Mishima A, Shimoda S, Hamada Y, Kobayashi K. Detection of buccal perimandibular neurovascularisation associated with accessory foramina using limited cone-beam computed tomography and gross anatomy. Surg Radiol Anat 2011;33:141-146.

366. Yu Q, Pan XG, Ji GP, Shen G. The association between lower incisal inclination and morphology of the supporting alveolar bone--a cone-beam CT study. Int J Oral Sci 2009;1:217-223.

367. Angel JS, Mincer HH, Chaudhry J, Scarbecz M. Cone-beam computed tomography for analyzing variations in inferior alveolar canal location in adults in relation to age and sex. J Forensic Sci 2011;56:216-219.

368. Michetti J, Maret D, Mallet JP, Diemer F. Validation of cone beam computed tomography as a tool to explore root canal anatomy. J Endod 2010;36:1187-1190.

369. Patel S. The use of cone beam computed tomography in the conservative management of dens invaginatus: a case report. Int Endod J 2010;43:707-713.

370. Huang CC, Chang YC, Chuang MC, Lai TM, Lai JY, Lee BS, Lin CP. Evaluation of root and canal systems of mandibular first molars in Taiwanese individuals using cone-beam computed tomography. J Formos Med Assoc 2010;109:303-308.

371. Kottoor J, Velmurugan N, Sudha R, Hemamalathi S. Maxillary first molar with seven root canals diagnosed with cone-beam computed tomography scanning: a case report. J Endod 2010;36:915-921.

372. La SH, Jung DH, Kim EC, Min KS. Identification of independent middle 
mesial canal in mandibular first molar using cone-beam computed tomography imaging. J Endod 2010;36:542-545.

373. Deguchi T Sr, Katashiba S, Inami T, Foong KW, Huak CY. Morphologic quantification of the maxilla and the mandible with cone-beam computed tomography. Am J Orthod Dentofacial Orthop 2010;137:218-222.

374. Kottoor J, Hemamalathi S, Sudha R, Velmurugan N. Maxillary second molar with 5 roots and 5 canals evaluated using cone beam computerized tomography: a case report. Oral Surg Oral Med Oral Pathol Oral Radiol Endod 2010;109:e162-165.

375. Bornstein MM, Wiest R, Balsiger R, Reichart PA. Anterior Stafne's bone cavity mimicking a periapical lesion of endodontic origin: report of two cases. J Endod 2009;35:1598-1602.

376. Pires CA, Bissada NF, Becker JJ, Kanawati A, Landers MA. Clin Implant Mandibular incisive canal: cone beam computed tomography. Dent Relat Res 2012;14:67-73.

377. Naitoh M, Nakahara K, Hiraiwa Y, Aimiya H, Gotoh K, Ariji E. Observation of buccal foramen in mandibular body using cone-beam computed tomography. Okajimas Folia Anat Jpn 2009;86:25-29.

378. Tu MG, Huang HL, Hsue SS, Hsu JT, Chen SY, Jou MJ, Tsai CC. Detection of permanent three-rooted mandibular first molars by cone-beam computed tomography imaging in Taiwanese individuals. J Endod 2009;35:503-507.

379. Naitoh M, Hiraiwa Y, Aimiya H, Gotoh K, Ariji E. Accessory mental foramen assessment using cone-beam computed tomography. Oral Surg Oral Med Oral Pathol Oral Radiol Endod 2009;107:289-294.

380. Katakami K, Mishima A, Shiozaki K, Shimoda S, Hamada Y, Kobayashi K.Characteristics of accessory mental foramina observed on limited cone-beam computed tomography images. J Endod 2008;34:1441-1445.

381. Popat H, Drage N, Durning P. Mid-line clefts of the cervical vertebrae - an incidental finding arising from cone beam computed tomography of the dental patient. Br Dent J 2008;204:303-306.

382. Sato I, Arai H, Asaumi R, Imura K, Kawai T, Yosue T. Classifications of tunnel-like structure of human petrotympanic fissure by cone beam CT. Surg Radiol Anat 2008;30:323-326. 
383. King KS, Lam EW, Faulkner MG, Heo G, Major PW. Vertical bone volume in the paramedian palate of adolescents: a computed tomography study. Am J Orthod Dentofacial Orthop 2007;132:783-788.

384. Rouas P, Nancy J, Bar D. Identification of double mandibular canals: literature review and three case reports with $\mathrm{CT}$ scans and cone beam CT. Dentomaxillofac Radiol 2007;36:34-38.

385. Liu DG, Zhang WL, Zhang ZY, Wu YT, Ma XC. Three-dimensional evaluations of supernumerary teeth using cone-beam computed tomography for 487 cases. Oral Surg Oral Med Oral Pathol Oral Radiol Endod 2007;103:403-411. 